\title{
Quantitative Gradient Echo MRI Identifies Dark Matter as a New Imaging Biomarker of Neurodegeneration that Precedes Tissue Atrophy in Early Alzheimer Disease
}

Satya V.V.N. Kothapalli ${ }^{1}$, Tammie L. Benzinger ${ }^{1,2}$, Andrew. J. Aschenbrenner ${ }^{2,3}$, Richard. J. Perrin $^{2.3,4,5}$, Charles. F. Hildebolt ${ }^{1}$, Manu. S. Goyal ${ }^{1,3}$, Anne. M. Fagan ${ }^{2,3,5}$, Marcus. E. Raichle ${ }^{1,3,5}$, John. C. Morris ${ }^{2,3}$, and Dmitriy. A. Yablonskiy ${ }^{1,2,5, *}$

\section{Affiliations:}

${ }^{1}$ Department of Radiology, Washington University in St. Louis, St. Louis, MO 63110, USA.

${ }^{2}$ Knight Alzheimer Disease Research Center, Washington University in St. Louis, St. Louis, MO 63110, USA.

${ }^{3}$ Department of Neurology, Washington University in St. Louis, St. Louis, MO 63110, USA.

${ }^{4}$ Department of Pathology and Immunology, Washington University in St. Louis, St. Louis, MO 63110, USA.

${ }^{5}$ The Hope Center for Neurological Disorders, Washington University in St. Louis, St. Louis, MO, USA

*Correspondence to:

Dmitriy A. Yablonskiy, PhD

Mallinckrodt Institute of Radiology, Washington University, 4525 Scott Ave. Room 3216

St. Louis MO, 63110

e-mail: YablonskiyD@wustl.edu

https: BMRL-DmitriyYablonskiy

Tel.: +1(314)362-1815; Fax: +1(314)362-0526

Funding: This study was supported by the NIH grants R01 AG054513, P50 AG0581, P01 AG03991, P01 AG026276, and The Clinical Core of the Knight Alzheimer Disease Research Center for participant characterization. 
medRxiv preprint doi: https://doi.org/10.1101/2021.04.27.21256098; this version posted April 29, 2021. The copyright holder for this preprint (which was not certified by peer review) is the author/funder, who has granted medRxiv a license to display the preprint in perpetuity.

All rights reserved. No reuse allowed without permission.

\begin{abstract}
:
Background: Currently, brain tissue atrophy serves as in vivo MRI biomarker of neurodegeneration in Alzheimer Disease (AD). However, postmortem histopathological studies show that neuronal loss in $\mathrm{AD}$ exceeds volumetric loss of tissue and that loss of memory in $\mathrm{AD}$ begins when neurons and synapses are lost. Therefore, in vivo detection of neuronal loss prior to detectable atrophy in MRI is essential for early AD diagnosis.

Objective: To apply a recently developed quantitative Gradient Recalled Echo (qGRE) MRI technique for in vivo evaluation of neuronal loss in human hippocampus.

Methods: Seventy participants were recruited from the Knight Alzheimer Disease Research Center, representing three groups: Healthy controls [Clinical Dementia Rating ${ }^{\circledR}(\mathrm{CDR} ®)=0$, amyloid $\beta$ (A $\beta$ )-negative), $n=34]$; Preclinical AD (CDR=0, A $\beta$-positive, $n=19)$; and mild AD $(\mathrm{CDR}=0.5$ or $1, \mathrm{~A} \beta$-positive, $\mathrm{n}=17)$.

Results: In hippocampal tissue, qGRE identified two types of regions: one, practically devoid of neurons, we designate as "Dark Matter", the other, with relatively preserved neurons - "Viable Tissue". Data showed a greater loss of neurons than defined by atrophy in the mild AD group compared with the healthy control group - neuronal loss ranged between $31 \%$ and $43 \%$ while volume loss ranged only between $10 \%$ and 19\%. The concept of Dark Matter was confirmed with histopathological study of one participant who underwent in vivo qGRE 14 months prior to expiration.
\end{abstract}

Conclusion: in vivo qGRE method identifies neuronal loss that is associated with impaired ADrelated cognition but is not recognized by MRI measurements of tissue atrophy, therefore providing new biomarkers for early AD detection.

Key words: qGRE; Alzheimer Disease; Hippocampus; Neurodegeneration; Cognitive Impairment; Brain Atrophy, Magnetic Resonance Imaging. 
medRxiv preprint doi: https://doi.org/10.1101/2021.04.27.21256098; this version posted April 29, 2021. The copyright holder for this preprint (which was not certified by peer review) is the author/funder, who has granted medRxiv a license to display the preprint in perpetuity.

All rights reserved. No reuse allowed without permission.

\section{Introduction}

Alzheimer disease (AD) is a progressive neurodegenerative disorder with typical clinical symptoms of memory loss, global cognitive decline, and behavioral changes, which eventually impact daily living activities [1]. It is well-known that pathological changes in the human brain begin decades before the appearance of clinical AD symptoms [2-6]. Magnetic resonance imaging (MRI) studies indicate that hippocampal atrophy (loss of tissue) is one of the earliest indications of AD pathology that can be detected through morphological studies [7-10]. The hippocampus is a complex structure that consists of several subregions that include dentate gyrus (DG), cornu ammonis (CA1, CA2, CA3, and CA4), subiculum and molecular layer (ML) [11]. Importantly, neurofibrillary tangles (NFT), a hallmark of AD, typically demonstrate a characteristic pattern of evolution across hippocampal subfields--first appearing in the CA1 and then spreading to other subfields $[12,13]$. The hippocampal subfields have different functions and network connections $[11,14,15]$ and show different vulnerabilities to neuropathologic insults (e.g., CA4 and CA1 to hypoxic/ischemic injury and excitotoxicity). Advances in MRI acquisition and image processing techniques allow segmentation of these sub-regions for investigating their volumetric and morphometric properties in relation to various neurodegenerative diseases [16]. Reports have shown that different hippocampal subfields exhibit differential vulnerability to various neurodegenerative disease pathologies, and variable involvement at different stages of these diseases [17, 18]. In $\mathrm{AD}$, however, morphometric alternations have been detected in multiple hippocampal subfields [15, 19-21] and were associated with mild cognitive impairment [22, 23].

While volumetric MRI-based measurement of atrophy is usually assumed to serve as an in vivo biomarker of neuronal loss [24], histopathological studies demonstrate that neuronal loss in the hippocampus actually exceeds loss of tissue volume [25]. This result is consistent with the finding of a widespread reduction of synapses that were more extensive than decreases in gray matter volume [26]. Importantly, symptoms of Alzheimer disease appear after sufficient neuronal [25, 27] and synaptic [28, 29] losses have occurred. Additionally, studies demonstrate that the extent of neuronal loss varies across hippocampal subfields, e.g., severe neuronal loss is observed in CA1 with less severe loss in subiculum regions [30]. Hence, in vivo assessment of neuronal loss in hippocampal subfields may serve as a more effective biomarker for disease progression than will measures of atrophy.

Our approach to assessing neuronal damage in vivo is based on (a) the quantitative Gradient Recalled Echo (qGRE) MRI technique [31] and (b) genetically-informed quantitative relationships between qGRE metrics and major components of brain tissue cellular structure (neurons/neurites and glia) [32]. The qGRE technique provides quantitative, non-invasive, in vivo, high-resolution $3 \mathrm{D}$ measurements of several brain-tissue-specific relaxation properties (qGRE metrics) of the gradient recalled echo (GRE) MRI signal that depend on brain cellular structure and functioning. Specifically, qGRE separates the GRE MRI signal decay R2* (=1/T2*) into its two main components, $\mathrm{R} 2 \mathrm{t}^{*}$ ( $\mathrm{t}$ stands for tissue) and R2'. The R2t* relaxation parameter depends solely on the cellular and subcellular microstructure [32], whereas R2' relates to the GRE signal loss due to the presence of paramagnetic deoxyhemoglobin in venous blood and adjacent to it part of the capillary bed (BOLD effect) [33, 34]. The basis of R2* disentanglement into R2t* and R2' is grounded in our previously developed theoretical model of BOLD signal [34] validated in phantom [35] and animal [36] studies. By introducing a concept of cells as an endogenous contrast agent, a quantitative relationship between the R2t* qGRE metric and Neuronal Density Index (NDI) - a 
medRxiv preprint doi: https://doi.org/10.1101/2021.04.27.21256098; this version posted April 29, 2021. The copyright holder for this preprint (which was not certified by peer review) is the author/funder, who has granted medRxiv a license to display the preprint in perpetuity.

All rights reserved. No reuse allowed without permission.

parameter that represents a proxy for the neuronal density - was established in Ref. [32] (see further details below in the Methods section).

In this study, we demonstrate that the qGRE R2t* metric identifies two different types of tissues in the hippocampal subfields of people with preclinical and mild AD dementia: one type - tissue with markedly lower neuronal content (that we term "Dark Matter" as it appears dark on R2t* images), and another type - tissue with a relatively preserved concentration of neurons (that we term "Viable Tissue"). We demonstrate that the qGRE-measured volumes of Viable Tissue and Dark Matter account for more significant differentiation between healthy participants and people with preclinical and mild AD than the total volume measurements by morphometric MRI. Likewise, the volumes of Viable Tissue and Dark Matter have stronger association with memory scores as compared with total volume. Finally, our preliminary data show that premortem in vivo $\mathrm{R} 2 \mathrm{t}^{*}$-based measurement of neuronal content in hippocampal subfields correspond to postmortem neuronal counts in an individual investigated by histopathology.

\section{Results}

Detailed procedures of generating qGRE-based metrics of Dark Matter, Viable Tissue and Neuronal Density Index are provided in the Methods section.

\section{AD-related neurodegeneration (neuronal damage) affects all hippocampal subfields}

The group comparisons of Dark Matter fraction, total volume, and Viable Tissue volume measurements between $\mathrm{HC}, \mathrm{PC}$, and mild AD groups in the hippocampal subfields are presented in Figure 1. We found no significant differences ( $p>0.05)$ between the $\mathrm{HC}$ and PC groups in total volume, which is in good agreement with previous histological [25] and longitudinal MRI [37] studies. Consistent with previous reports [21, 38, 39], we also found decreased volume in all hippocampal subfields in the mild AD group compared with the $\mathrm{PC}$ and $\mathrm{HC}$ groups though in some subfields (e.g. CA1) these differences did not reach the significance threshold (most likely due to the small sample sizes). This result is consistent with both 3T [38] and 7T MRI studies of hippocampal subfield volumes [40]. The significant volume differences between the mild AD and $\mathrm{HC}$ groups in our data are seen in all subfields except in CA1 and CA2/3 regions. Further, group differences $(\mathrm{p}<0.05)$ between mild AD and PC are seen in all subfields except in CA1. Compared with total tissue volume, Viable Tissue, and Dark Matter volumes show stronger group separation in most hippocampal subfields (Figure 1). Unlike total volume measurements, the Viable Tissue volumes in all hippocampal subfields in the mild $\mathrm{AD}$ group differ from those of the $\mathrm{HC}$ group and PC group $(\mathrm{p}<0.05)$. The Dark Matter fraction exhibits group differences between mild AD and HC $(\mathrm{p}<0.01)$ in all subfields and exhibits differences between $\mathrm{PC}$ and mild $\mathrm{AD}(\mathrm{p}<0.05)$ in CA1, CA2/3, CA4, GC-DG, and ML regions. Importantly, statistically significant group differences in Dark Matter fraction were found between HC and PC $(\mathrm{p}<0.05)$ in the parasubiculum, subiculum, CA1, and ML regions.

The last panel in Figure 1 represents measurements of neuronal density in the Viable Tissue of all hippocampal subfields. It is evident that mean value of NDI of the Viable Tissue in mild AD is decreased as compared with $\mathrm{HC}$ or PC. However, the one-way ANOVA multi comparison identified significant differences between $\mathrm{HC}$ and mild $\mathrm{AD}$ observed only in specific subfields, such as CA2/3, GC-DG, and HP tail regions, and significant group differences between PC and mild $\mathrm{AD}$ was observed only in $\mathrm{CA} 2 / 3$ region. This finding remarkably indicates that neurons are only marginally decreased in the Viable Tissue while major neuronal loss is related to the presence 
of Dark Matter. The lower mean NDI in the mild AD group might be attributed to increased microglia cell activity in the Viable Tissue in mild AD compared with HC or PC tissue.

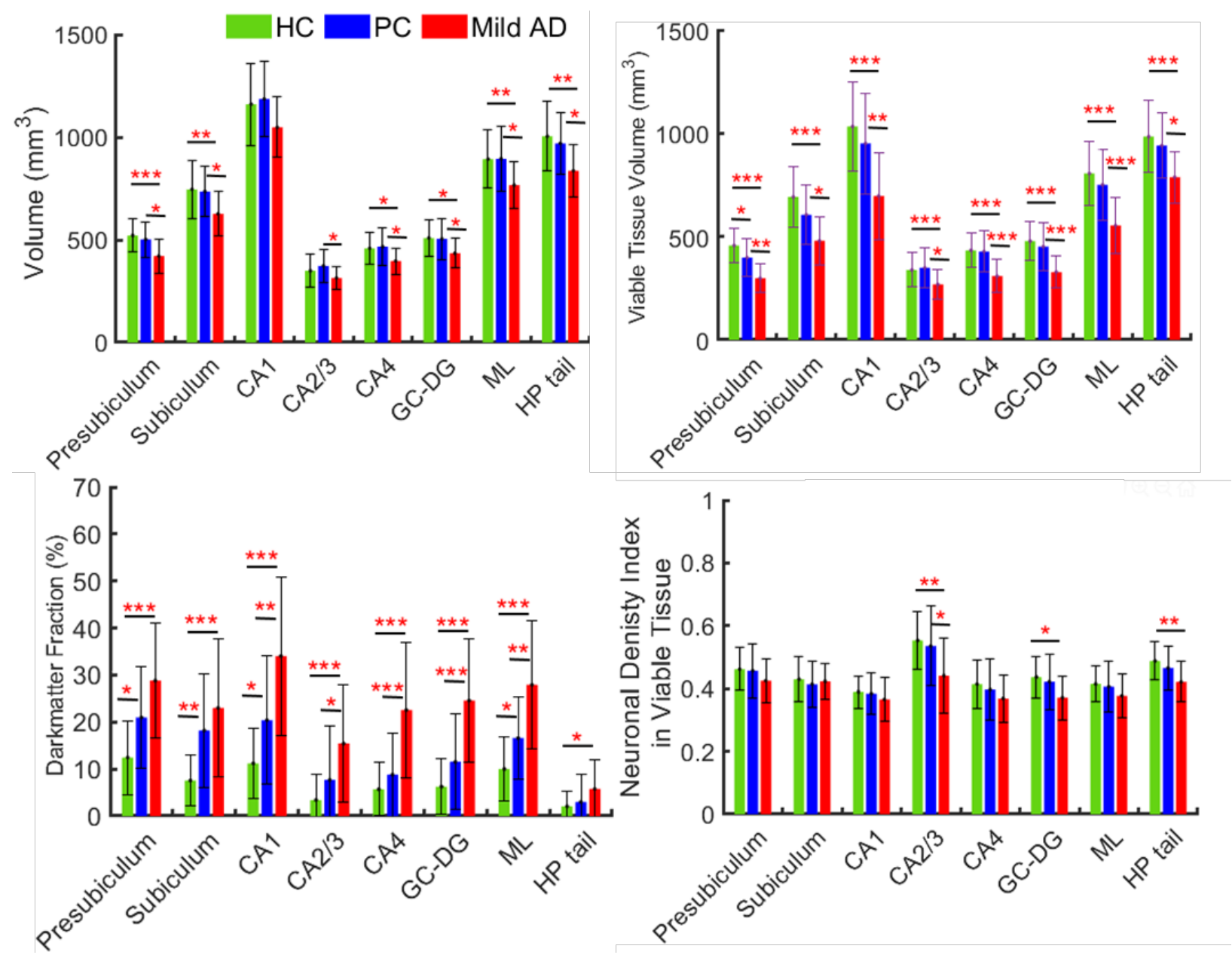

Figure 1. Total volume, Viable Tissue volume, Dark Matter fraction, and Neuronal Density Index of the viable tissue in hippocampal subfields. Bars represent mean group values and whiskers show standard deviations. Green bars represent the HC group ( $n=34)$, blue bars represent PC group $(n=19)$, and red bars represent mild $\mathrm{AD}(\mathrm{n}=17)$ group. Herein, the "“*” corresponds to $\mathrm{p}<0.05$, “**” to $\mathrm{p}<0.01$, “***” to $\mathrm{p}<0.001$.

\section{Neuronal loss exceeds volumetric loss of tissue in hippocampal subfields}

Data in Figure 2 shows loss of neurons and tissue volume in the mild AD group relative to the HC group. The mean volume loss fraction of the mild AD group is about $19 \%$ in presubiculum, $16 \%$ in subiculum, $10 \%$ in CA1, 10\% in CA2/3, 14\% in CA4, 15\% in GC-DG, $14 \% \mathrm{ML}$, and 17\% in $\mathrm{HP}$ tail with respect to the $\mathrm{HC}$ group. Previous studies have reported that the overall hippocampal volume was lower by $15-30 \%$ in mild AD compared with $\mathrm{HC}$ [41]. In our findings, a volume reduction was about $10-19 \%$ in the mild $\mathrm{AD}$ group compared with the $\mathrm{HC}$ group, which is consistent with previous findings. The mean neuronal loss fraction in the mild AD group is about $40 \%$ in presubiculum, $32 \%$ in subiculum, $37 \%$ in $\mathrm{CA} 1,37 \%$ in $\mathrm{CA} 2 / 3,38 \%$ in $\mathrm{CA} 4,43 \%$ in GCDG, $38 \% \mathrm{ML}$, and $31 \%$ in HP tail. These data show significantly higher neuronal loss as compared with volume loss in the mild $\mathrm{AD}$ group. This result is consistent with previous findings [25] that 
medRxiv preprint doi: https://doi.org/10.1101/2021.04.27.21256098; this version posted April 29, 2021. The copyright holder for this preprint (which was not certified by peer review) is the author/funder, who has granted medRxiv a license to display the preprint in perpetuity.

All rights reserved. No reuse allowed without permission.

reported about $46 \%$ of neuronal loss and $29 \%$ of volumetric loss (about 1.6 times lower than neuronal loss) in the CA1 region in the AD postmortem brains compared with cognitively normal brains. The presence of Dark Matter (i.e. brain tissue with significantly lower concentration of neurons with their processes, hence less restrictions for water diffusion) can also explain previously reported measurements of increased Apparent Diffusion Coefficient in hippocampus of people with mild cognitive impairment [42].

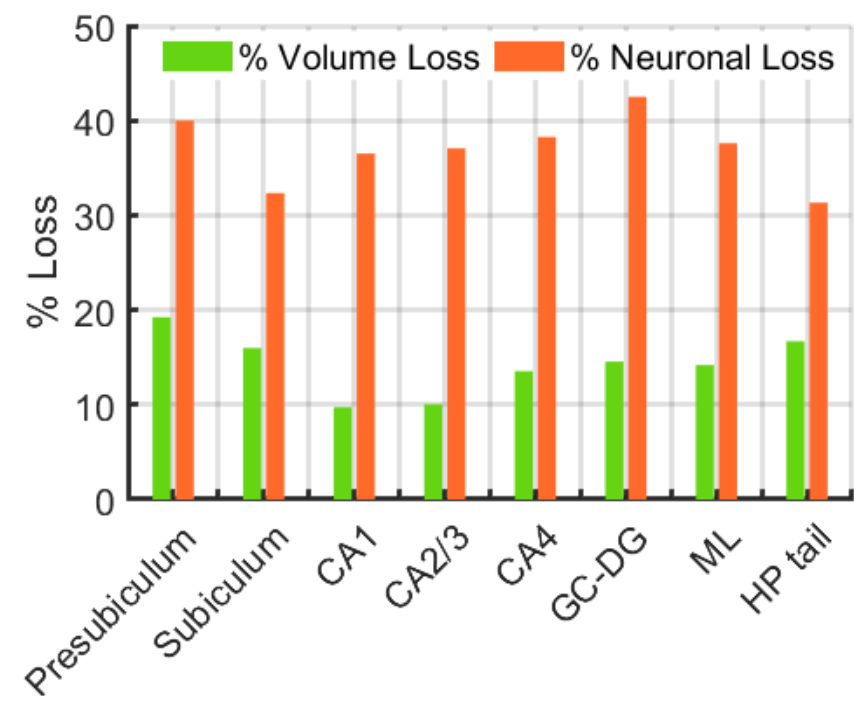

Figure 2. Percent of volume and neuronal losses in mild $\mathrm{AD}$ group in hippocampal subfields evaluated with respect to the group mean values of $\mathrm{HC}$ group.

Dark Matter fraction and the Viable Tissue volume exhibit stronger associations with neurocognitive scores than volumetric measurements

The outcomes of linear regression analyses between the global cognitive composite and the Free and Cued Selective Reminding Test, (FcSRT, as a measure of episodic memory) and imaging scores (qGRE biomarkers of Viable Tissue volume and Dark Matter fraction, along with the Total Volume measurements in global hippocampus) are presented in Figure 3. Outcomes from the individual cognitive tests are presented in Supplemental Figure S1. The Dark Matter fraction is negatively associated with episodic memory $(\mathrm{R}=-0.47$; $\mathrm{p}=0.0001)$, meaning that higher Dark Matter fraction correlates with worse memory performance, while the Total Volume exhibits a positive but much weaker association $(\mathrm{R}=0.23$; $\mathrm{p}=0.07)$, i.e., lower the volume lower the episodic memory scores. A similar trend is seen for the global cognitive composite, though in this case, the Dark Matter fraction and the Total Volume shows similar correlations, while the strongest association is seen with the Viable Tissue Volume $(\mathrm{R}=0.53, \mathrm{p}<0.0001)$.

Our results for the Total Volume measurements indicate that smaller hippocampal volumes are associated with worse cognitive performance, consistent with the previous studies [43] [44]. Plots in Figure 3 and Supplemental Figure S1 show a positive association with FcSRT, global cognition, letter number sequencing, category fluency and negative associations (as expected) with the Trail Making A and B tests. 

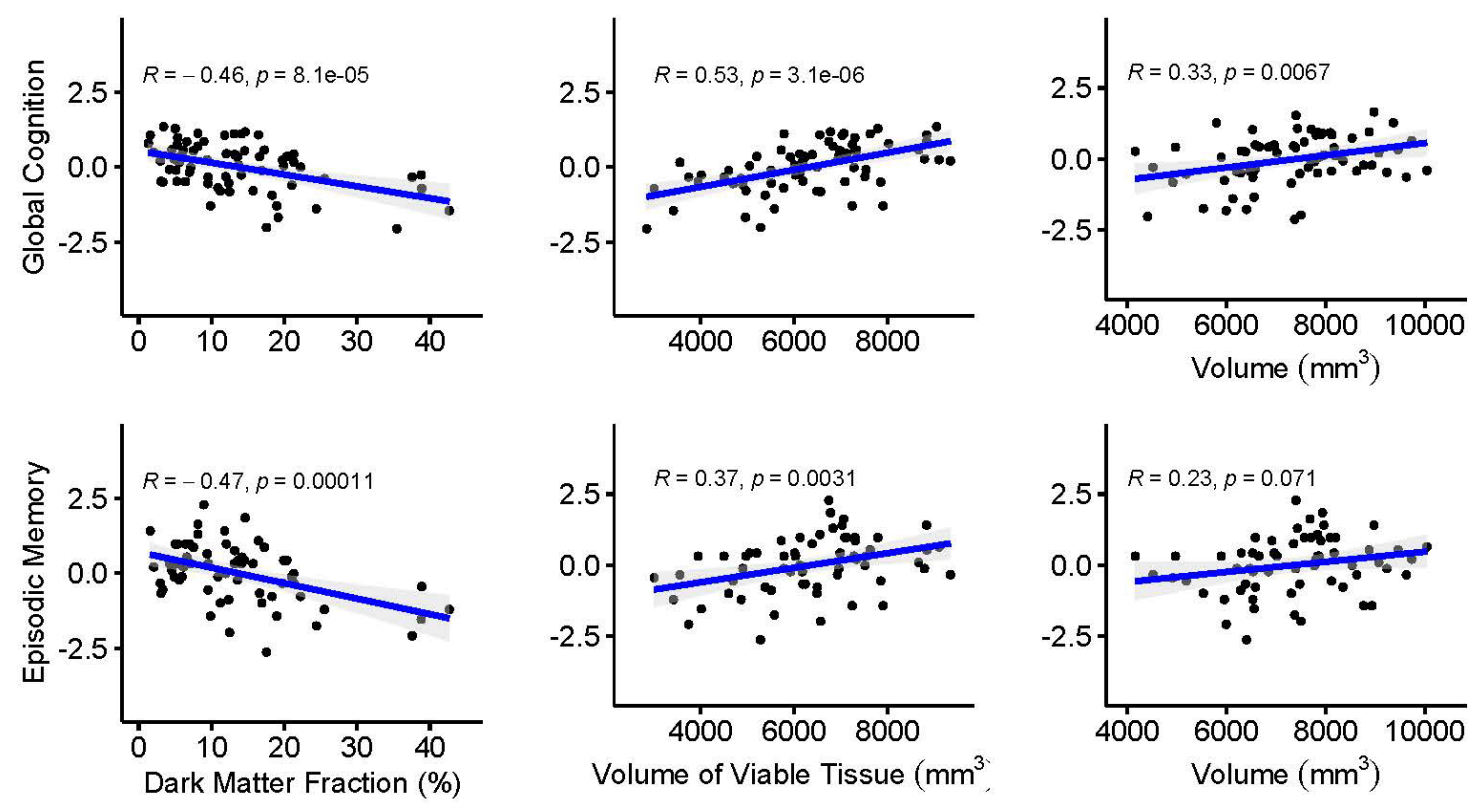

Figure 3. Correlation of two cognitive scores: z-scores of Global Cognition and Episodic Memory (represented by the Global Memory Composite and the Free and Cued Selective Reminding Test, respectively) vs. fraction of Dark Matter, volume of Viable Tissue, and Total Volume of the hippocampus. Each point represents an individual participant. All individual cognitive data are presented in Supplemental Figure S1.

Volumes of Hippocampal Dark Matter and Viable Tissue provide new biomarkers for classification of $H C, P C$, and mild AD groups

In this section, we present the results of our second set of data analyses that are based on global hippocampal measures and use these biomarkers to demonstrate that the new qGRE metrics (Dark Matter and Viable Tissue volumes) represent clinically important differences between groups as compared with differences based on hippocampal atrophy (reduction of hippocampal volume). Results based on the values of the individual biomarkers are shown in Figure 4. The box plots illustrate the clinical importance of differences among the values for the HC, PC and mild AD groups in the hippocampus. These differences among groups were assessed with a generalized linear model with a normal distribution and an identity link function. As part of this analysis, to assess differences between groups, contrast analyses were performed. Although the use of a generalized linear model does not require the assumptions of data normality or equality of variances, for each model a studentized deviance residual plot was created and examined to detect trends that were not captured by the model. For these analyses, the data distributions in the studentized deviance residual plots were judged acceptable. To partially control for these multiple assessments, alpha was set at 0.01 . 


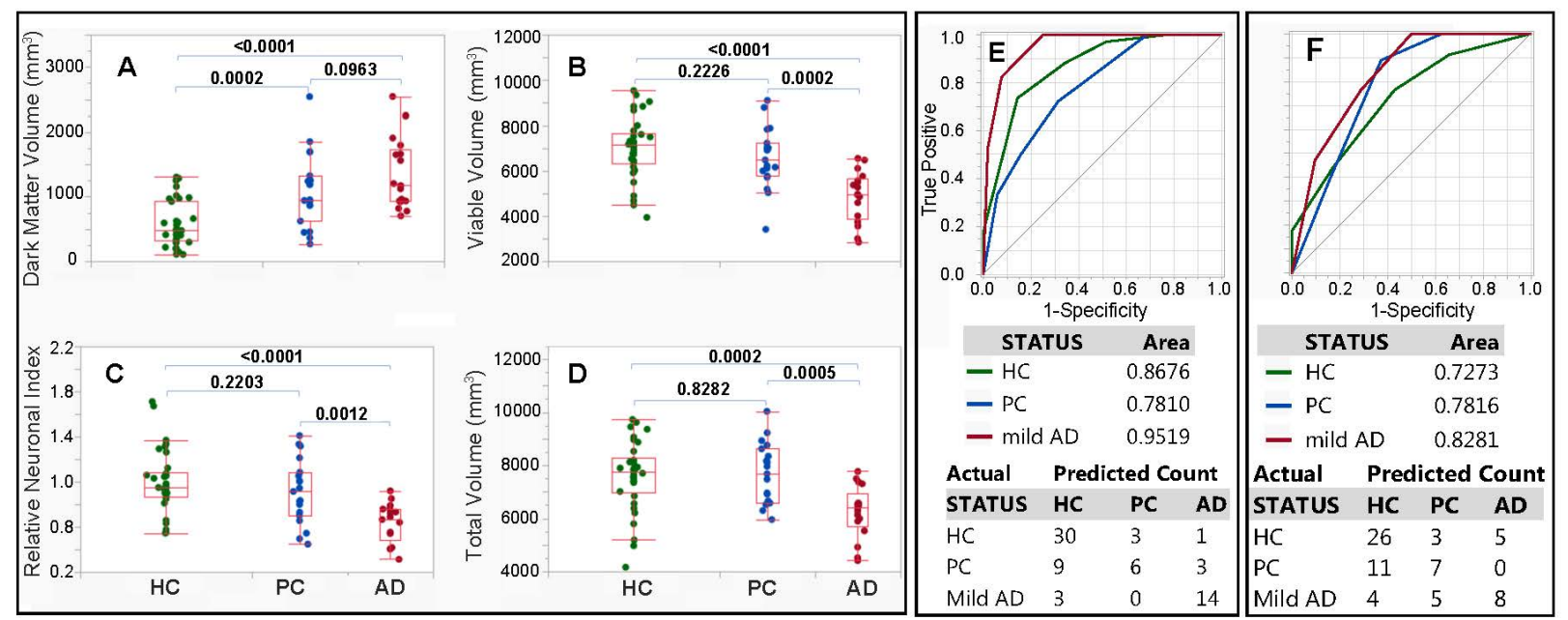

Figure 4. Group differences (A-D) and ROC classifications (E, F) based on qGRE metrics and volumetric measurements in the hippocampus. (A) Dark Matter volume $\left(\mathrm{mm}^{3}\right),(\mathbf{B})$ Viable Tissue volume $\left(\mathrm{mm}^{3}\right),(\mathbf{C})$ Relative Neuronal Index (total number of neurons normalized by the mean value of the total number of neurons in the HC group), and (D) Total Volume $\left(\mathrm{mm}^{3}\right)$. The middle lines of the box plots represent median, ends of the boxes are the 25th and 75th quantiles (quartiles), and interquartile range is the difference between the quartiles. The lines (whiskers) extend from the boxes to the outermost points that fall within the distance computed as 1.5 (interquartile range). All generalized linear models for A, B, C, and D indicated differences among the $\mathrm{HC}, \mathrm{PC}$, and $\mathrm{AD}$ groups $(\mathrm{p} \leq 0.0004)$ and the $\mathrm{p}$ values that resulted from assessing differences between groups are indicated above the horizontal connectors between groups. (E) Result of a classification-tree that was produced using global hippocampal Dark Matter volume and Viable Tissue volume variables as predictors. (F) Result of a classification-tree that was produced using Total Hippocampal Volume as predictor. Receiver operating characteristic (ROC) curves, areas under the curves (AUCs), and a confusion matrix are presented. The confusion matrix presents the numbers of correct and incorrect classifications. ROC analysis is performed by constructing a graph of true and false positive rates (sensitivity and 1 minus specificity, respectively) for a series of cutoff points for a test (in our case, MRI metrics). The ROC curve yields a measure of diagnostic accuracy, independent of the decision criterion. It characterizes the inherent accuracy of the technique. The AUC value represents the probability that a randomly chosen abnormal case is (correctly) rated or ranked with greater suspicion than a randomly chosen normal case.

The findings demonstrate that while total hippocampal volume results in statistically significant differences between the mild $\mathrm{AD}$ group and the $\mathrm{HC}$ and $\mathrm{PC}$ groups, it does not result in a statistically significant difference between the PC and HC groups. At the same time, the Dark Matter volume is significantly elevated in PC group as compared with the HC group and may, thus, serve as a biomarker for early AD pathology. Note that, even after excluding the outlier with unusually high Dark Matter Volume $\left(2542 \mathrm{~mm}^{3}\right.$ - higher than any other participant in our study, including participants with AD) from the PC group (Figure 4A), the difference between the HC and $\mathrm{PC}$ groups remains highly significant $(\mathrm{p}=0.0008)$, and the $\mathrm{p}$ value for the difference between the PC and mild AD groups decreases ( $\mathrm{p}=0.0218$ vs. 0.0963 in Figure 4A). Though, the outlier participant is cognitively normal, her very high Dark Matter volume is consistent with elevated tauopathy standard uptake value ratio (1.77) and the lower episodic memory score, which is close to the mean cognitive score of the mild AD group (mean FcSRT score of mild AD group was about 16.5, and the FcSRT score for this participant was 16). Presumably, this participant might progress 
medRxiv preprint doi: https://doi.org/10.1101/2021.04.27.21256098; this version posted April 29, 2021. The copyright holder for this preprint (which was not certified by peer review) is the author/funder, who has granted medRxiv a license to display the preprint in perpetuity.

All rights reserved. No reuse allowed without permission.

to symptomatic $\mathrm{AD}$ very soon, or might have unknown factors conferring cognitive resilience. This outlier was further excluded from classification tree analysis.

Results for the neuronal content show similar values in the HC and PC groups but an impressively lower number of neurons in the mild AD participants. These assessments were performed to estimate population parameters.

In addition, models were used to calculate each participant's probability of being a member of each of the three groups, and each participant was classified to the group for which the participant had the highest probability of group membership. Based upon these probabilities, receiver operating characteristic (ROC) curves were created for the classifications for each group, with the goal being to determine how accurately classification-tree models classified all of the participants. The classification tree's success in classifying participants to each group is illustrated with each group's ROC curve, which is a plot of sensitivity against the false-positive rate (that is, 1 minus the specificity). The area under the curve (AUC) is an indication of the model's diagnostic performance. For the target classification (for instance HC), an AUC value is equal to the probability that a randomly chosen $\mathrm{HC}$ participant is (correctly) rated or ranked with greater suspicion than a randomly chosen PC or mild AD participant. An area of 0.5 represents chance performance. In building a classification tree model, because of the relatively small sample sizes, $\mathrm{k}$-fold cross validation (with 5 folds) was used. To prevent overfitting the model, the k-fold cross validation stopping rule was used to terminate stepping when improvement in the cross validation RSquare was minimal. The use of classification trees requires no implicit assumption that the underlying relationships between the predictor variables and the dependent variables are linear, follow some specific nonlinear link function (as with generalized linear and nonlinear models) or are even monotonic in nature - that is, they are non-parametric and nonlinear. They are also easy to interpret in that they are based on a series of nested if-then statements.

The qGRE biomarkers in the hippocampus (Dark Matter and Viable Tissue volumes) were used as predictors to build a classification tree, and the results are shown in Figure $\mathbf{4 E}$ and Supplemental material (Figures S2, S3, and S4). Results of a classification tree with the Total Volume as a predictor are shown in Supplementary Figure S5. As indicated in the classification tree (Figure S2, the majority (25 of 34) of HC participants had low Dark Matter volume (less than $704 \mathrm{~mm}^{3}$ ). Of the remaining $9 \mathrm{HCs}$ with Dark Matter volume larger than $704 \mathrm{~mm}^{3}, 8$ had high "compensating" Viable Tissue volume $\left(>5782 \mathrm{~mm}^{3}\right)$. On the other hand, the majority of participants from the PC group (13 of 18) had Dark Matter volume larger than $704 \mathrm{~mm}^{3}$ with 6 having high Viable Tissue volume $\left(>6922 \mathrm{~mm}^{3}\right), 4$ participants with Viable Tissue volume between $5782 \mathrm{~mm}^{3}$ and $6922 \mathrm{~mm}^{3}$, and 3 below $5782 \mathrm{~mm}^{3}$. All 17 participants with mild AD had Dark Matter volume greater than $704 \mathrm{~mm}^{3}$ with the majority (9) having low Viable Tissue volume of less than $5044 \mathrm{~mm}^{3}$; 5 having Viable Tissue volumes between $5044 \mathrm{~mm}^{3}$ and $5782 \mathrm{~mm}^{3}$, and only 3 having Viable Tissue volumes larger than $5782 \mathrm{~mm}^{3}$ (though less than $6922 \mathrm{~mm}^{3}$ ). Thus, Dark Matter volume was an important biomarker separating participants belonging to HC and PC groups, while Viable Tissue volume played an important role in separating the HC and PC groups from the mild AD group.

ROC-based comparisons of classification results based qGRE metrics versus commonly used tissue atrophy are shown in Figure 4 and Supplementary Figure S6. Significant differences in the AUC values for the ROC curves were found for HC $(p=0.0304)$ and mild AD $(p=0.0016)$. For Dark Matter and Viable Tissue volumes AUC was $0.8676(0.7662-0.9291,95 \%$ confidence interval (CI)) and for Total Volume the AUC value was $0.7273(0.5989-0.8265,95 \% \mathrm{CI})$ with p 
medRxiv preprint doi: https://doi.org/10.1101/2021.04.27.21256098; this version posted April 29, 2021. The copyright holder for this preprint (which was not certified by peer review) is the author/funder, who has granted medRxiv a license to display the preprint in perpetuity.

All rights reserved. No reuse allowed without permission.

$=0.0304$. The corresponding results for PC were $0.7810(0.6496-0.8729,95 \% \mathrm{CI})$ and 0.7816 $(0.6636-0.8665,95 \% \mathrm{CI}), \mathrm{p}=0.9940$, and for mild AD, $0.9519(0.8838-0.8910,95 \% \mathrm{CI})$ and $0.8281(0.7129-0.9033,95 \% \mathrm{CI}), \mathrm{p}=0.0016$.

Data demonstrate that all AUC values for the ROC curves for Dark Matter and Viable Tissue volumes and for Total volumes had $\mathrm{p}$ values $<0.0001$. For further comparison, for each ROC curve, the Youden Index was used to select the point at which the sensitivity and specificity were optimized. Results using Volumes of Dark Matter and Viable tissue are: for HC, the optimal sensitivity and specificity were 73.53 (55.6 - 87.1, 95\% confidence interval (CI)) and $85.71(69.7$ $-95.20,95 \% \mathrm{CI})$, for PC, the optimal sensitivity and specificity were $72.22(46.5-90.3,95 \% \mathrm{CI})$ and $68.63(54.1-80.9,95 \% \mathrm{CI})$, and for mild AD, the optimal sensitivity and specificity values were $100.00(80.5-100.0)$ and $75.00(61.1$ - 86.0). Difference between these independent ROC curves were assessed using the AUC values their standard errors. The resulting $\mathrm{p}$ values were: 0.2143 for $\mathrm{HC}$ versus PC, 0.0698 for $\mathrm{HC}$ versus mild AD, and 0.0053 for PC versus mild AD.

Corresponding values were calculated for Total Tissue volumes. For HC, the optimal sensitivity and specificity were $76.47(58.8-89.3,95 \% \mathrm{CI})$ and $57.14(39.4-73.7,95 \% \mathrm{CI})$. For PC, the optimal sensitivity and specificity values were $88.89(65.3-98.6,95 \% \mathrm{CI})$ and $62.75(48.1-75.9$, $95 \% \mathrm{CI})$. For mild AD, the optimal sensitivity and specificity values of $100.00(80.5-100.0,95 \%$ $\mathrm{CI})$ and $50.00(35.8-64.2,95 \% \mathrm{CI})$ were found. Difference between these independent ROC curves were assessed using the AUC values their standard errors. The results were not significant as $\mathrm{p}$ values were: 0.4883 for $\mathrm{HC}$ versus $\mathrm{PC}, 0.1841$ for $\mathrm{HC}$ versus mild $\mathrm{AD}$, and 0.5111 for PC versus mild $A D$.

The classification results presented in Figure $4 \mathbf{E}$ can be further improved by including two biological variables (age or gender) in two different classification trees (Figure S3 and Figure S4). By including age, the area under the ROC curve (AUC) increased to 0.8312 for PC but remained practically the same for $\mathrm{HC}$ and mild AD. Including gender also increased the area under the ROC curve for PC to 0.8115 , but the areas under the ROC curves remained practically the same for the $\mathrm{HC}$ and mild $\mathrm{AD}$ groups. The confusion matrices show that the combination of the Viable Tissue volume and Dark Matter volume with either age or gender improves identification of participants in the PC group. Our assessments demonstrate that volumes of Hippocampal Dark Matter and Viable Tissue provide useful biomarkers for group classification (HC, PC and mild AD). There are many additional brain areas that could be included in building classification trees, and our expectation is that the inclusion of these additional ROIs will result in improved classification results.

Association between Dark Matter and direct neuronal count - Preliminary Data

For one participant who expired and underwent postmortem neuropathologic examination, subjective assessment by an experienced neuropathologist found severe loss of neurons in the parasubiculum, the subiculum, and CA1, and modest losses in CA2/CA3 and CA4. Exemplar photomicrographs from CA1 and CA2/CA3 hippocampal subfields are presented in Figure 5). These relative neuronal densities align with qGRE measurements that showed a large portion of Dark Matter around the head of the hippocampus (first row in Figure 5) - in parasubiculum (25\% of Dark Matter), subiculum (18\% of Dark Matter), and CA1 (23\% of Dark Matter) regions. We found relatively low Dark Matter fraction in CA2/CA3 (3\%) and CA4 (10\%) regions, which exhibit relative neuronal preservation, as assessed histologically. We also found strong interregional association $\left(\mathrm{R}^{2}=0.78\right)$ between in vivo qGRE measurements of Dark Matter fraction and 
medRxiv preprint doi: https://doi.org/10.1101/2021.04.27.21256098; this version posted April 29, 2021. The copyright holder for this preprint (which was not certified by peer review) is the author/funder, who has granted medRxiv a license to display the preprint in perpetuity.

All rights reserved. No reuse allowed without permission.

an average neuronal count $(\mathrm{N})$ in $40 x$ objective fields $(\mathrm{N}=8$ in parasubiculum, $\mathrm{N}=1$ in subiculum, $\mathrm{N}=3$ in $\mathrm{CA} 1, \mathrm{~N}=59$ in $\mathrm{CA} 2 / \mathrm{CA} 3$, and $\mathrm{N}=21$ in CA4) in the postmortem study. Additional information is presented in Supplemental Table $\mathrm{S} 1$.

Our preliminary data provide direct validation of the Dark Matter concept, using qGRE to accurately identify brain regions with substantial neuron losses that are not readily detectable on T1-weighted images. This further indicates that in vivo qGRE measurement is sensitive for detecting neuronal loss as compared with T1-weighted based volumetric approach.

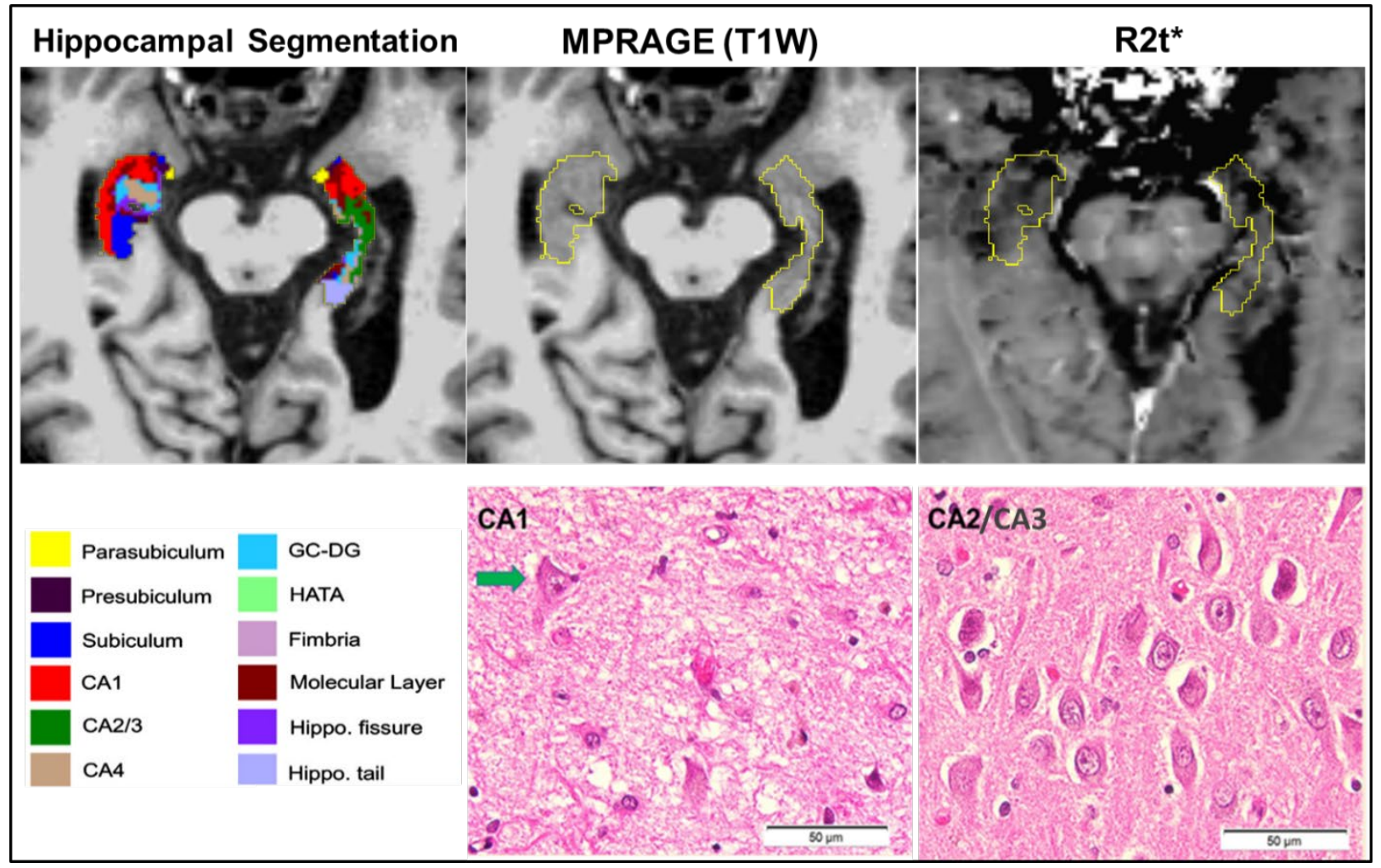

Figure 5. Data obtained from a study participant with a clinical diagnosis of AD dementia (CDR 1). Upper panel - in vivo MPRAGE and qGRE images. Lower panel - postmortem neuropathological examination. qGRE $R 2 t^{*}$ in the hippocampus (outlined in yellow with hippocampal subfields shown in colors, segmented based on FreeSurfer) shows Dark Matter (hypointense lesions with lower $R 2 t^{*}$ values) in parts of subiculum, parasubiculum and CA1, indicating the loss of neurons. This is confirmed by direct neuropathological examination shown in the lower panel obtained from the postmortem studies from this participant. Severe neuronal loss in CA1 (hematoxylin and eosin stain) is reflected by the presence of only one remaining definitively identifiable neuron (indicated by the arrow) within this representative image; relative neuronal preservation is shown in a representative photomicrograph from CA2/CA3. Unlike qGRE $R 2 t^{*}, \mathrm{~T} 1$-weighted MPRAGE imaging finds the hippocampal region to be practically homogeneous without any obvious intensity contrast. Hence, the data demonstrate a higher sensitivity of qGRE $R 2 t^{*}$ measurements to tissue neuronal loss as compared with standard volumetric measurements. Scale bars are 50 micrometers.

\section{Discussion}

This study demonstrates that the qGRE method identifies neuronal loss within hippocampal subfields that is associated with impaired cognition but is not recognized by MRI measurements of tissue atrophy. The onset of neurodegeneration in Alzheimer disease is known to start several 
medRxiv preprint doi: https://doi.org/10.1101/2021.04.27.21256098; this version posted April 29, 2021. The copyright holder for this preprint (which was not certified by peer review) is the author/funder, who has granted medRxiv a license to display the preprint in perpetuity.

All rights reserved. No reuse allowed without permission.

years prior to detectable clinical symptoms [2-6] but usually cannot be appreciated, using conventional neuroimaging techniques (i.e. volumetric measurements of tissue atrophy) [6]. A recently proposed $\mathrm{A} / \mathrm{T} / \mathrm{N}$ framework describes a classification system based on the pathological changes accompanying AD progression [24]. With this approach, A refers to amyloidosis, T refers to neurofibrillary tangles, and $\mathrm{N}$ refers to neurodegeneration or neuronal injury. Biomarkers for $\mathrm{A}$ or T classification include positron emission tomography (PET) and/or cerebrospinal fluid (CSF) measurements, which are well correlated with Braak stages [45]. Losses of neuronal structure or function are defined as neurodegeneration (N) with relevant biomarkers including CSF tau, FDGPET hypometabolism, and structural MRI (measurement of tissue atrophy). Compared with other techniques, structural MRI (usually T1-weighted MPRAGE) offers high resolution 3D images with good gray/white matter contrast that allow accurate measurement of brain regional volumes and their changes in AD (see recent review [46]). In particular, hippocampal atrophy has been connected to age-related pathology [47] and cognitive impairment [48]; however, as was demonstrated in patients with $\mathrm{AD}$ [49], hippocampal regions that have almost isointense contrast on structural MRI might have important variations in measurements of $\mathrm{R} 2 \mathrm{t}^{*}$, reflecting variation in tissue cellular integrity that was correlated with cognitive impairment. This is because T1weighted imaging only provides the information on global tissue atrophy but is not sensitive to the microstructural changes at the cellular level (i.e. inflammation, loss of neurons, synapses, etc.) in the existing not-atrophied tissue. Consistent with R2t*-based measurement [49], T2-based measurements also identified tissue heterogeneity in hippocampus [50]. Moreover, they found that T2-identified tissue heterogeneity was a better predictor of cognitive decline in MCI participants than mean T2. Several other MRI methods [e.g. diffusion tensor imaging [51], quantitative susceptible mapping [52], arterial spin labeling measurements of the cerebral blood flow [53], Magnetic Resonance Spectroscopy [54]] also reported AD-related changes in brain tissue structure and functioning.

Our approach for evaluation of AD-related tissue cellular damage is based on quantitative Gradient Recalled Echo (qGRE) MRI [31] that allows direct mapping of biomarkers related to human brain cellular composition [32]. qGRE technique is based on a high resolution gradient recalled echo MRI sequence with multiple gradient echoes (available from most MRI manufacturers), the method for separation of cellular specific $\left(\mathrm{R} 2 \mathrm{t}^{*}\right)$ and BOLD contributions to the R2* decay of the GRE signal [31], and a quantitative relationship between qGRE R2t* metric and tissue neuronal density that was derived in [32] by analyzing an association between maps of $\mathrm{R} 2 \mathrm{t}^{*}$ and maps of gene expression profiles obtained from the Allen Human Brain Atlas. This relationship is in concert with a proposed hypothesis [55] that the $\mathrm{R} 2 \mathrm{t}^{*}$ parameter can be used as a correlate of cellular structure in healthy brain as well as cellular integrity changes in mild AD [49].

In our study, we used qGRE R2t* mapping to introduce two new quantitative MRI biomarkers to better characterize AD-related, brain-tissue pathology especially at early, preclinical stages of Alzheimer disease - Dark Matter (brain tissue practically devoid of neurons), and Viable Tissue (tissue with a relatively preserved concentration of neurons). The key finding of this study demonstrates that the changes in hippocampal volumes of Viable Tissue and Dark Matter are more sensitive than changes in global hippocampal volume (atrophy) for differentiating healthy control participants from preclinical and mild AD participants, thus providing early biomarkers of neurodegeneration in preclinical AD. Our data also show that the hippocampal volumes of Dark Matter (increased even in preclinical AD stages), and Viable Tissue (decreased with AD 
medRxiv preprint doi: https://doi.org/10.1101/2021.04.27.21256098; this version posted April 29, 2021. The copyright holder for this preprint (which was not certified by peer review) is the author/funder, who has granted medRxiv a license to display the preprint in perpetuity.

All rights reserved. No reuse allowed without permission.

progression) are more sensitive correlates of cognitive performance than the global volume of the hippocampus (decreased only in AD stages).

One of the significant consequences of the presence of Dark Matter (and relative preservation of neuronal concentration in the Viable Tissue) is a faster rate of neuronal loss as compared with tissue atrophy. This finding is important due to early observations that the neuron number in layer II of entorhinal cortex determines whether individuals with the neuropathology of Alzheimer disease manifest symptoms: there is little or no neuronal loss in individuals who did not have symptoms of AD during life, whereas individuals with even the earliest symptomatic stages of the disease already had substantial neuronal loss $[25,27]$. Hence, it is critical to get in vivo information on neurodegeneration prior to their detection by standard volumetric measurements. Our data demonstrate greater changes in Dark Matter and Viable Tissue (reflecting higher neuronal loss; $31-43 \%$ in different hippocampal subfields) as compared with volume loss $(10-19 \%$ in these subfields) in the mild AD group, relative to HC. This result is consistent with previous findings [25] that reported about $46 \%$ of neuronal loss and $29 \%$ of volumetric loss (about 1.6x lower than neuronal loss) in CA1 region in the AD postmortem brains compared with brains from those who died with normal cognition.

While no previous report exists on Dark Matter measurements, our findings can be associated with the presence of neurofibrillary tangles (NFT) - a neuropathologic feature most relevant to neuronal loss. In our study, qGRE measurements showed the presence of Dark Matter in the hippocampal tissue even in healthy elderly individuals (age $72 \pm 6$ years) who are cognitively normal and without amyloid pathology. From NFT perspective, this is consistent with the presence of NFT in cognitively normal older adults [56-58]. Furthermore, the Dark Matter volume increase of about $2.9 \mathrm{x}$ in the mild AD group compared with the normal control group is consistent with findings of an autopsy study [59] that reported a $\sim 2.7 \mathrm{x}$ higher concentration of NFTs in the entorhinal cortex of the participants with mild cognitive impairment (MCI) as compared with cognitively normal individuals. Of note, the preclinical designation in our study is not the same as MCI in [59], as our 'preclinical 'designation is assigned to participants without cognitive impairment but with amyloid pathology, whereas the term 'MCI' classification is based on the presence of cognitive impairment only.

Results shown in Figure 4 and Supplementary Figure S6 demonstrate advantages of using new qGRE metrics versus commonly used tissue atrophy for participants' classification between Healthy Control, Preclinical and Mild AD groups. Detailed statistical analyses showed that the AUC values resulting from the ROC curves for Dark Matter with Viable Tissue volumes and for Total volume were all significant $(\mathrm{p}<0.0001)$. However, for Total volume, none of the AUC values were different from one another $(\mathrm{p} \geq 0.1841)$, while for Dark Matter and Viable Tissue volumes, the AUC value for mild AD was significantly higher than that for PC $(p=0.0053)$ and approached being significantly different from $\mathrm{HC}(\mathrm{p}=0.0698)$. In addition, for mild AD, the AUC value for Dark Matter with Viable Tissue volumes was significantly higher than the AUC value for Total volume $(p=0.0016)$, and the same was true for $\mathrm{HC}(\mathrm{p}=0.0340)$. The AUC values for Dark Matter with Viable Tissue volumes and Total volumes were highest for mild AD (respectively, 0.9519 and 0.8281 , for which the optimal sensitivities for both methods were 100\%; however, the optimal specificity for Total volume (50\%) was significantly lower than for Dark Matter with Viable Tissue (75\%).

In this study, all hippocampal subfields had lower volume (atrophy) in mild AD when compared with HC group, with the maximum volume loss in the presubiculum, followed by smaller volume 
medRxiv preprint doi: https://doi.org/10.1101/2021.04.27.21256098; this version posted April 29, 2021. The copyright holder for this preprint (which was not certified by peer review) is the author/funder, who has granted medRxiv a license to display the preprint in perpetuity.

All rights reserved. No reuse allowed without permission.

reductions in the ML and HP tail regions. These results are consistent with the literature on hippocampal subfields volumetric studies that report lower volumes in different hippocampal subfields in patients with AD compared with cognitively normal individuals [21, 39, 60, 61]. Several imaging [62-64], autopsy [25, 30, 65, 66], and animal [67] studies demonstrate the early involvement of the $\mathrm{CA} 1$ region in $\mathrm{AD}$-related neurodegeneration. While our analysis also showed volume reduction in CA1, it did not reach our statistical threshold for our sample of participants, most likely due to insufficient sample size. However, our Viable Tissue volume measurements that consider microstructural neuronal damage, demonstrated differences in the CA1 region between mild AD and HC. In addition, our findings suggest that the volumes of Viable Tissue and Dark Matter can be better candidates than volumetric measurements for predicting cognitive performance. For example, Free and Cued Selective Reminding Test with Immediate Recall (FcSRT) has been widely used to distinguish AD-related dementia from non-AD-related dementia $[68,69]$, and this neuropsychological test is considered to be the best candidate for episodic memory [70] assessment. A previous study reported a positive but rather weak $(\mathrm{r} \sim 0.3)$ association between hippocampal volume and the FcSRT in a population between 65-80 years [71]. In our participants, the volumetric data also show a positive but weak association between total hippocampal volume and the FcSRT ( $\mathrm{r} \sim 0.23$ ) but relatively stronger associations with qGRE hippocampal metrics - volume of Viable Tissue ( $\mathrm{r}$ 0.37) and Dark Matter fraction ( $\mathrm{r}-0.47)$.

Our study has several limitations. First, the association between R2t* and NDI was derived in [32] for healthy control brains, and this relation might not directly translate for diseased brains. Hence, NDI in AD brain can be treated as an apparent proxy for neuronal density. Other pathological changes in tissue microstructure (e.g. axonal demyelination, depletion of ferritin iron, etc.) that are concomitant with neuronal loss can also potentially lead to reduced R2t*. Further neuropathological studies are required for establishing more detailed information on the relationship between $\mathrm{R} 2 \mathrm{t}^{*}$ and tissue cellular composition. In this study, we deduced a NDI only for viable tissue but used a $5.8 \mathrm{~s}^{-1}$ threshold for Dark Matter separation from Viable Tissue for all study participants. However, additional analysis presented in Figure S7 shows that our main conclusions are quite stable and the $\mathrm{R} 2 \mathrm{t}^{*}=5.8 \mathrm{~s}^{-1}$ threshold for Dark Matter separation used in our study is also a reasonable criterion for assessment in AD-related participants. Our study had relatively small numbers of participants in each group--a larger study is underway that will further improve the statistical power of our findings. Further, herein we presented a single case of direct histopathological validation of Dark Matter representation as a tissue with significantly lower neuronal content not readily detectable with traditional volumetric measurements. A larger study is also underway to further validate this concept. While in this study we used hippocampal segmentation based on FreeSurfer software, new tools [72] can be more sensitive for specific AD pathology in the hippocampus.

In summary, the key finding of this study is demonstrating that the changes in hippocampal volumes of Viable Tissue and Dark Matter are more sensitive than the changes in global hippocampal Tissue Volume (atrophy) for differentiating healthy control participants from preclinical and mild AD groups, thus providing early biomarkers of preclinical AD pathology. Our data also show that the hippocampal volumes of Dark Matter (increased even in preclinical AD stages) and Viable Tissue (decreased with AD progression) are more sensitive correlates of cognitive performance than the global volume of the hippocampus (decreased only in symptomatic AD stages). 
medRxiv preprint doi: https://doi.org/10.1101/2021.04.27.21256098; this version posted April 29, 2021. The copyright holder for this preprint

(which was not certified by peer review) is the author/funder, who has granted medRxiv a license to display the preprint in perpetuity.

All rights reserved. No reuse allowed without permission.

Our approach is based on the qGRE method utilizing a multi-gradient-echo MRI sequence available from most MRI manufacturers and required only about 6 minutes of MRI scanning time. Data analysis can be significantly accelerated with the aid of deep learning method [73], thus opening opportunity for broad research and clinical applications. Combining in vivo qGRE biomarkers of neuronal injury with the current in vivo PET and CSF biomarkers would allow for better understanding and detection of the early pathology in Alzheimer disease and other dementias.

\section{Methods}

\section{Participants}

Seventy (70) participants, ages between 60 and 90 years $(73.5 \pm 6.6)$, were recruited through the Knight Alzheimer Disease Research Center (ADRC) and signed the informed consent document. Demographic information available on this cohort is presented in Table 1. Combined MRI and histopathology data from one more additional participant were used for cross-correlation analysis. This study was approved by the Institutional Review Board (IRB) of Washington University School of Medicine.

\section{$\underline{\text { Cognitive assessment }}$}

All participants of the Knight ADRC complete comprehensive clinical and cognitive assessments. The presence and severity of dementia symptoms was determined using the Clinical Dementia

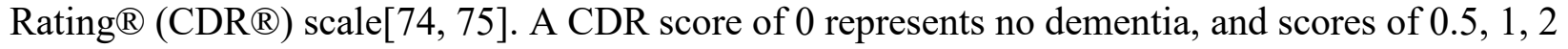
and 3 represent very mild, mild, moderate, and severe dementia, respectively, based on exam and collateral source interview. Tests given in the neuropsychological evaluation vary slightly depending on the participant's age upon entry into the study. Tests administered to all participants include the Free and Cued Selective Reminding Test (FcSRT) [76], Trail Making Part A and B [77], Category Fluency [78] for Animals, and Letter Number Sequencing [79] from the Wechsler Memory Scale-III. A global cognitive score was formed as a Z-scored composite of Category Fluency, FcSRT, Trail Making A and B, and letter number sequencing. Episodic memory was represented by the FcSRT. Global cognition test scores were available on 68 participants and the FcSRT scores were available for 62 participants.

\section{Cerebrospinal fluid (CSF) amyloid measurements}

The CSF biomarker A $\beta 42$ test (INNOTEST, Fujirebio, Gent, Belgeium) was performed with a standardized protocol via lumbar puncture. Using the abnormal A $\beta 42$ cutoff value, participants were separated into $A \beta$ positive and negative groups [80].

\section{Group classification}

Seventy participants were classified into three groups based on CDR score and $A \beta_{42}$ status (as shown in Table 1): 1 . Healthy control $(\mathrm{HC})(\mathrm{CDR}=0 ; \mathrm{A} \beta 42=$ negative; $n=34) ; 2$. Preclinical $A D$ (PC) $(\mathrm{CDR}=0 ; \mathrm{A} \beta 42=$ positive; $\mathrm{n}=19)$; and 3. mild $\mathrm{AD}(\mathrm{CDR}>0 \quad[\mathrm{CDR}=0.5$ for 14 participants and $\mathrm{CDR}=1$ for 3 participants $] \& \mathrm{~A} \beta 42=$ positive; $n=17$ ). Note that in our consideration we use the term "Preclinical AD" generally accepted in the field as reflecting abnormal biomarkers of amyloid-beta and tau (or the postmortem presence of Alzheimer neuropathology) in asymptomatic 
persons. This is in part because we and others have demonstrated that preclinical AD is associated with progression to symptomatic Alzheimer disease, whether preclinical Alzheimer disease was detected by amyloid PET [81] or by abnormal CSF concentrations of A $\beta 42$ or tau [82]. This classification corresponds to "Alzheimer's pathologic change" in the recent NIA-AA framework research criteria [24, 83].

The mean and standard deviation values of cognitive test scores and participants' ages in HC, PC, and mild AD groups are presented in Table 1. There was no difference between groups based on age ( $p=0.4$ between HC and PC, $p=0.99$ between AD and PC, and $p=0.46$ between AD and HC). All cognitive tests (except TMA test) exhibit group differences $(p<0.05)$ between $\mathrm{HC}$ and mild $\mathrm{AD}$ but no group differences between the HC and PC groups ( $\mathrm{p}>0.05)$. Global cognition, FcSRT, letter number sequencing test..

Table 1. Participants' demographic information and the mean and standard deviation of age and neuropsychometric scores of three groups which are classified based on the CDR and A $\beta 42$ status. $\$$ indicates a significant $(\mathrm{p}<0.05)$ group difference between $\mathrm{HC}$ and mild $\mathrm{AD}$ groups, $\uparrow$ indicates a significant $(\mathrm{p}<0.05)$ group differences between $\mathrm{PC}$ and mild $\mathrm{AD}$ groups, and $\neq$ indicates a significant $(\mathrm{p}<0.05)$ group differences between HC and PC groups. The Global test is presented as a z-score of combined Animals, Free and Cued Selective Reminding Test (FcSRT), Trail Making A (TMA) and B (TMB), and letter number tests. The rest of the tests are presented as actual individual scores. Note that TMA and TMB are scored such that higher is worse.

\begin{tabular}{|c|c|c|c|c|}
\hline & Total & $\begin{array}{c}\mathrm{HC} \\
\mathrm{CDR}=0 \text { \& } \mathrm{A} \beta \\
\text { status }= \\
\text { Negative }\end{array}$ & $\begin{array}{c}\mathrm{PC} \\
\mathrm{CDR}=0 \& \\
\mathrm{~A} \beta \text { status }= \\
\text { Positive }\end{array}$ & $\begin{array}{c}\text { Mild AD } \\
\text { CDR }=0.5,1 \\
\& \text { A } \beta \text { status }= \\
\text { Positive }\end{array}$ \\
\hline $\mathrm{N}$ & 70 & 34 & 19 & 17 \\
\hline $\begin{array}{c}\text { Gender } \\
\text { (Female/Male) }\end{array}$ & $31 / 39$ & $19 / 15$ & $8 / 11$ & $4 / 13$ \\
\hline Age & $73.5 \pm 6.6$ & $72.2 \pm 6.1$ & $74.7 \pm 7.3$ & $74.6 \pm 6.8$ \\
\hline †tGlobal & $0.0 \pm 0.8$ & $0.4 \pm 0.6$ & $0.1 \pm 0.8$ & $-0.8 \pm 0.7$ \\
\hline$\dagger+$ FcSRT & $27.1 \pm 9.2$ & $31.9 \pm 6.4$ & $27.5 \pm 8.3$ & $17.7 \pm 7.7$ \\
\hline$\dagger$ †MA & $35.8 \pm 15.7$ & $30.9 \pm 10.4$ & $36.2 \pm 18.4$ & $44.6 \pm 17.9$ \\
\hline †TMB & $91.2 \pm 39.6$ & $80.0 \pm 30.7$ & $85.0 \pm 36.4$ & $114.8 \pm 46.4$ \\
\hline †tAnimals & $20.0 \pm 6.0$ & $21.9 \pm 5.7$ & $20.2 \pm 5.6$ & $16.2 \pm 5.6$ \\
\hline $\begin{array}{l}+\dagger \text { Letter Number } \\
\text { sequencing }\end{array}$ & $8.9 \pm 2.8$ & $10.0 \pm 2.5$ & $9.1 \pm 2.3$ & $6.8 \pm 2.6$ \\
\hline
\end{tabular}

\section{Postmortem study}

In this study we used data from a participant who was diagnosed with dementia $(C D R=1)$. The participant underwent in vivo qGRE MRI measurements about one year prior to expiration. Neuropathological analysis was performed by a highly experienced board-certified neuropathologist, blinded to any neuroimaging data or formal neuropathologic diagnosis at the time of cell counting. Brain-only autopsy yielded the following neuropathologic findings: hippocampal sclerosis with neocortical and limbic TDP-43 proteinopathy; low Alzheimer disease neuropathologic change (A2, B1, C1 by NIA-AA criteria); mild aging-related tau astrogliopathy 
medRxiv preprint doi: https://doi.org/10.1101/2021.04.27.21256098; this version posted April 29, 2021. The copyright holder for this preprint (which was not certified by peer review) is the author/funder, who has granted medRxiv a license to display the preprint in perpetuity.

All rights reserved. No reuse allowed without permission.

(ARTAG); and mild vasculopathy (arteriolosclerosis, cerebral amyloid angiopathy, and atherosclerosis). For this study, neuronal counts were performed on a six-micron-thick coronal section of formalin-fixed, paraffin-embedded tissue from the left hippocampal formation, sampled at the level of the lateral geniculate nucleus, and stained with hematoxylin and eosin (H\&E) histochemistry. Three 40x objective fields (each $0.55 \mathrm{~mm}$ diameter) selected for counting were evenly spaced but otherwise randomly chosen within each area of interest based on boundaries borrowed from FreeSurfer. Neurons were identified by morphology on H\&E stained slides.

\section{$\underline{\text { MRI data acquisition }}$}

Brain MRI data were acquired at Washington University in Saint Louis. The imaging protocol included the 3D multi gradient-recalled echo sequence and magnetization-prepared rapid gradientecho imaging (MPRAGE)[84]. Since data were collected over 4 years, four Siemens 3T MRI scanners were used (Siemens, Erlangen, Germany). The Fisher-Freeman-Halton test demonstrated that the three categories of participants $(\mathrm{HC}, \mathrm{PC}$, and mild AD) were independent $(P=0.2096)$ of the four different MRI scanners (PET-MR, Prisma, Trio, and VIDA). Details of the statistical analysis are presented in Table S2, therein. Details of qGRE data acquisition are provided in [31]. In brief, sequence parameters were: field of view (FOV) $256 \times 192 \mathrm{~mm}$, resolution $1 \times 1 \times 2 \mathrm{~mm}^{3}$ (read, phase, and slab directions), 10 gradient echoes with first echo time $4 \mathrm{~ms}$, echo spacing $4 \mathrm{~ms}$, repetition time $\mathrm{TR}=50 \mathrm{~ms}$, and flip angle $30^{\circ}$. A phase stabilization echo (navigator) was collected for each line in k-space to correct for image artifacts due to the physiological fluctuations [85]. Standard clinical T1-weighted MPRAGE images (FOV $=256 \times 256 \mathrm{~mm}$, $\mathrm{T} 1 / \mathrm{TE} / \mathrm{TR}=1100 / 3.37 / 2000 \mathrm{~ms}$, flip angle $=10^{\circ}$, acquisition time $=6 \mathrm{mins}$, and resolution $1 \times 1 \times 1 \mathrm{~mm}^{3}$ ) were acquired for image segmentation.

\section{qGRE data analysis}

The qGRE MRI method [31,32] is based on a multi-echo gradient echo sequence theoretical model of GRE signal decay[34, 35] and the relationships between GRE signal decay rate parameters and major elements of brain cellular structure (neurons/neurites and glia cells)[32]. Phase stabilization navigator pulses designed to reduce effects of physiological fluctuations are also incorporated in the sequence[85]. Data analysis was performed with a stand-alone computer with in-house developed programs written in MatLab (MathWorks Inc., Natick, MA, USA). After phase correction, k-space data from each radio frequency (RF) channel were converted to the spatial domain, and the 3D spatial Hanning filter was applied to reduce Gibbs ringing artifacts and signal noise. To achieve optimal model parameter estimations, the multi-channel data $(\mathrm{ch}=1,2, \ldots, \mathrm{M})$ were combined according to the following algorithm allowing the most accurate model parameters evaluation [86, 87]:

$$
S_{n}(T E)=\sum_{c h=1}^{M} \lambda_{c h} \cdot \bar{S}_{n}^{c h}\left(T E_{1}\right) \cdot S_{n}^{c h}(T E), \quad \lambda_{c h}=\frac{1}{M \cdot \varepsilon_{c h}^{2}} \sum_{c h^{\prime}=1}^{M} \varepsilon_{c h^{\prime}}^{2}
$$

Where $\bar{S}$ denotes the complex conjugate of $\mathrm{S}$; index n represents the voxel position in space; $\lambda_{\text {ch }}$ are weighting factors, and $\varepsilon_{\mathrm{ch}}$ are noise amplitudes (r.m.s.). 
medRxiv preprint doi: https://doi.org/10.1101/2021.04.27.21256098; this version posted April 29, 2021. The copyright holder for this preprint (which was not certified by peer review) is the author/funder, who has granted medRxiv a license to display the preprint in perpetuity.

All rights reserved. No reuse allowed without permission.

A theoretical model of BOLD (blood oxygen level dependent) contrast [88] was used to differentiate the contribution of tissue-cellular-specific relaxation (R2t*) and BOLD contributions to the total $\mathrm{R} 2 *$ relaxation $[31,35,88]$ :

$$
S(T E)=S_{0} \cdot \exp \left(-R 2 t^{*} \cdot\left(T E+T E_{1}\right)-\zeta \cdot f_{s}(\delta \omega \cdot T E)+i \cdot 2 \pi \cdot \Delta f \cdot\left(T E-T E_{1}\right)\right) \cdot F(T E)
$$

where $\mathrm{S}_{0}$ is the signal amplitude; $\delta \omega$ is the characteristic frequency determined by the susceptibility difference between deoxygenated blood and surrounding tissue; $\zeta$ is the volume fraction of deoxygenated blood; nonlinear function $f_{s}(\delta \omega \cdot T E)$ accounts for the BOLD effect [88]; and $\Delta \mathrm{f}$ is the local frequency shift, and the function $\mathrm{F}(\mathrm{TE})$ describes the effect of macroscopic magnetic field inhomogeneities with respect to gradient echo time TE [89]. Herein, F(TE) was calculated by a voxel spread function (VSF) method $[90,91]$ using a library-driven approach (45).

\section{Hippocampal segmentation and co-registration}

The hippocampal segmentation was performed on T1-weighted MPRAGE images using Freesurfer6.0 software (Laboratory for Computational Neuroimaging Martinos Center for Biomedical Imaging)[64]. The software provides 12 hippocampal volumes in each hemisphere: parasubiculum, presubiculum, subiculum, cornu ammonis (CA1, CA2/3, and CA4), molecular layer, granule cell layer of the dentate gyrus (GC-DG), hippocampus-amygdala transition area (HATA), fimbria, hippocampal tail (HP tail), and hippocampal fissure. The hippocampal white matter subfields and subfields with lower volumes (HATA, fimbria, hippocampal fissure, and parasubiculum) were excluded from the analysis[21]. The masks of hippocampal subfields in MPRAGE space were registered to the $\mathrm{S}_{0}$ qGRE images (that are T1-weighted images) by using FMRIB's Linear Image Registration tool in FSL software $[92,93]$. The resultant transformation matrices were inverted and applied to hippocampal subfield masks of naturally co-registered $\mathrm{S}_{0}$ maps of R2t*.

\section{qGRE metrics generation}

The parameters $\mathrm{S}_{0}, \mathrm{R} 2 \mathrm{t}^{*}, \Delta \mathrm{f}, \zeta$, and $\delta \omega$ in each voxel were estimated by fitting Eq. [2] to the complex MR signal in each voxel using a nonlinear least square curve fitting algorithm. The stability of the fitting procedure is described in previous publications [31, 55].

In a recent publication [32], gene expression profiles available from the Allen Human Brain Atlas were used to demonstrate that the network of genes related to neuronal brain structure has an expression profile similar to the $\mathrm{R} 2 \mathrm{t}^{*}$ relaxations profile across multiple regions in a human brain cortex. Based on this consideration, the authors deduced a quantitative relationship between the $\mathrm{R} 2 \mathrm{t}$ * metric and an index that can serve as a proxy for neuronal density (herein called the Neuronal Density Index, NDI):

$$
R 2 t^{*}=5.8+20.4 \cdot N D I \text {. }
$$

$\mathrm{R} 2 \mathrm{t}^{*}$ is measured in $\mathrm{sec}^{-1}$, and parameter NDI is dimensionless, which varies from 0 (index for tissue devoid of neurons) to 1 (index for tissue with $100 \%$ neurons).

The value of NDI in a healthy adult human brain varies approximately from 0.3-0.7 which correspond to $\mathrm{R} 2 \mathrm{t}^{*}$ approximately in the range between $12 \mathrm{~s}^{-1}$ and $20 \mathrm{~s}^{-1}$; however, data in our study revealed the presence of tissue with R2t* even smaller than $5.8 \mathrm{~s}^{-1}$, especially in people with AD. Since NDI $>0$, regions of the brain with $R 2 t^{*}$ smaller than $5.8 \mathrm{~s}^{-1}$ represent tissue practically 
devoid of neurons. Accordingly, with further analysis, we separated brain regions with R2t* smaller than $5.8 \mathrm{~s}^{-1}$ from regions with positive NDI (R2t* greater than $\left.5.8 \mathrm{~s}^{-1}\right)$. Tissue with $\mathrm{R} 2 \mathrm{t}^{*}<$ $5.8 \mathrm{~s}^{-1}$ is referred to as "Dark Matter" as it is seen as dark in R2t* images. Accordingly, the volume fraction of Dark Matter in a region of interest (ROI) is characterized by a ratio of Dark Matter volume to the total volume of the selected ROI. The neuron-containing tissue (R2t* $\left.>5.8 \mathrm{~s}^{-1}\right)$ is referred to as "Viable Tissue". Importantly, for all three groups, The R2t* distributions are significantly different between Dark Matter and Viable Tissue as shown in Supplemental Table $\mathrm{S} 3$. Note that mean $\mathrm{R} 2 \mathrm{t}^{*}$ values in the hippocampal viable tissue are in the range 14.3-15.2 $\mathrm{s}^{-1}$ (more than twice bigger than $5.8 \mathrm{~s}^{-1}$ threshold) corresponding to NDI index in the range of healthy tissue (as in Figure 1). At the same time, mean R2t* values in the Dark Matter more than twice smaller than $5.8 \mathrm{~s}^{-1}$ threshold. The choice of the R2t* threshold $\left(5.8 \mathrm{~s}^{-1}\right)$ that separates Dark Matter and Viable Tissue is further justified in Supplemental Figure S7. Schematic representation of separating Dark Matter and Viable Tissue is illustrated in Figure 6 along with examples of hippocampal Viable and Dark Matter Tissue images for three participants belonging to different groups - HC, PC and mild AD.

(A)

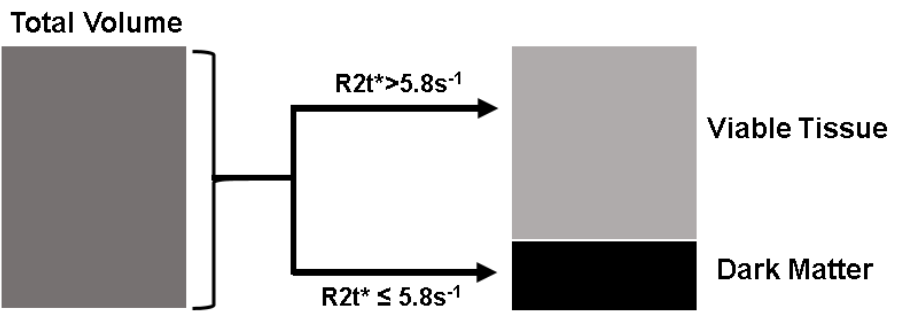

(B)
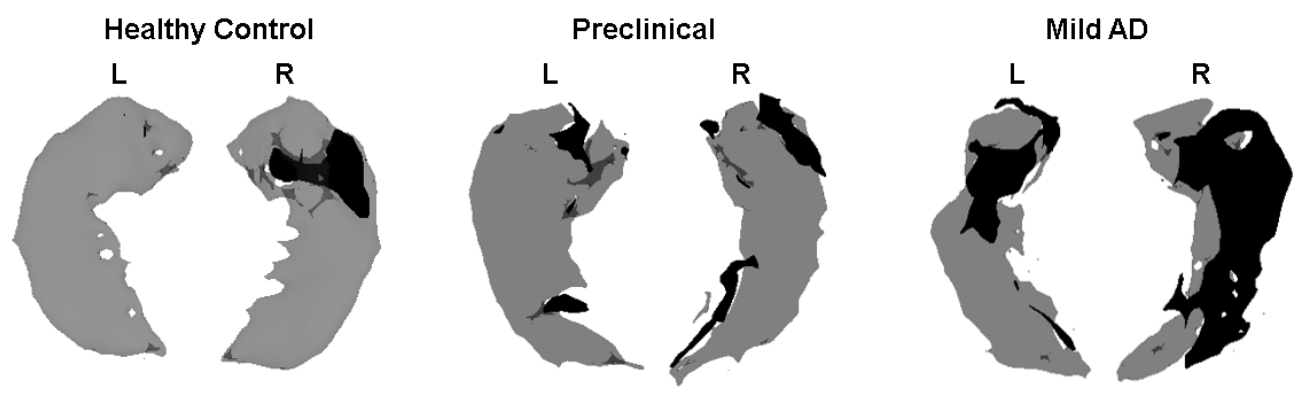

Figure 6. (A) Schematic representation of qGRE biomarkers. Total tissue volume identified on MRI images (e.g. T1-weighted MPRAGE) is separated into two volumes based on qGRE R2t* measurement: Dark Matter - tissue devoid of neurons $\left(\mathrm{R} 2 \mathrm{t}^{*}<5.8 \mathrm{~s}^{-1}\right)$ and Viable Tissue - tissue with relatively preserved neurons $\left(\mathrm{R} 2 \mathrm{t}^{*}>5.8 \mathrm{~s}^{-1}\right)$. (B) 3D surface views (created by using Slicer 4.5.0 software) of the hippocampus structure of three representative participants from HC, PC, and mild AD groups. Viable Tissue is marked with grey color and Dark Matter is marked with black color.

Note that Figure 6 shows left/right asymmetry, but this result did not reach significance at the group levels, most likely due to insufficient sample sizes. Hence, in all our consideration, we analyzed data by combining left and right hippocampal subfields. 
medRxiv preprint doi: https://doi.org/10.1101/2021.04.27.21256098; this version posted April 29, 2021. The copyright holder for this preprint

(which was not certified by peer review) is the author/funder, who has granted medRxiv a license to display the preprint in perpetuity.

All rights reserved. No reuse allowed without permission.

\section{Statistical Analyses}

For this study, two separate and independent statistical analyses of the collected data were performed. For the first set of analyses, the differences between Viable Tissue and Dark Matter volumes in the individual hippocampal subfields were assessed. For the second set of analyses, global hippocampal measures were used to assess how well the new qGRE metrics (Dark Matter and Viable Tissue volumes) represent clinically important differences between groups as compared with difference based on the hippocampal atrophy (reduction of hippocampal volume).

The first set of statistical analyses was performed using R software (version 22.0, Armonk, NY, United States) and MATLAB (MathWorks Inc., Natick, MA, United States). One-way analysis of variance (ANOVA) with multiple comparisons was performed to assess group differences between $\mathrm{HC}, \mathrm{PC}$, and mild AD groups based on qGRE metrics obtained from hippocampal subfields and global cognitive test scores. The associations between qGRE metrics and all cognitive scores were performed using linear regression analysis. From the regression analysis, the correlation coefficient (r) and significance ( $p$ ) were calculated. Because these analyses were considered preliminary and investigational, a $\mathrm{p}$ value less than 0.05 was considered a statistically significant difference and an $r$ value greater than 0.3 was considered a clinically important association between measurements.

For the second set of analyses, differences among groups were assessed with a generalized linear model, and classification tree analyses were used to calculate each participant's probabilities of being a member of each of the three groups. For the classification-tree analyses, receiver operating characteristic (ROC) curves were created, the areas under the curves (AUCs) were determined for each group and differences between groups determined. In addition, the values for Dark Matter and Viable Tissue volume were assessed for differences from those for Total Volume. For these analyses, the alpha level was set at 0.05 . For each ROC curve, it was determined the point at which sensitivity and specificity were maximized. These analyses were performed with JMP Pro Statistical Software Release 15.1.0 (SAS Institute, Inc., Cary, NC) and MedCalc Statistical Software version 19.6 (MedCalc Software Ltd, Ostend, Belgium; https://www.medcalc.org; 2020).

\section{Supplementary Materials}

Figure S1. Correlation of individual neurocognitive tests with fraction of Dark Matter, volume of Viable Tissue, and Total Volume of the hippocampus.

Figure S2. Classification tree analysis using Dark Matter and Viable Tissue volume parameters.

Figure S3. Classification tree analysis using Dark Matter and Viable Tissue volume parameters with taking account of participant's age.

Figure S4. Classification tree analysis using Dark Matter and Viable Tissue volume parameters with taking account of participant's gender information.

Figure S5. Results of a classification-tree that was produced using hippocampal Total Volume variable as a predictor.

Figure S6. ROC-based comparisons of classification results based qGRE metrics versus commonly used tissue atrophy. 
medRxiv preprint doi: https://doi.org/10.1101/2021.04.27.21256098; this version posted April 29, 2021. The copyright holder for this preprint (which was not certified by peer review) is the author/funder, who has granted medRxiv a license to display the preprint in perpetuity.

All rights reserved. No reuse allowed without permission.

Figure S7. The choice of R2t* threshold for justifying the separation of Dark Matter volume from Viable tissue volume.

Table S1. Summary of mean neuronal count and Dark Matter measurements in five hippocampal subfields.

Table S2. Statistical analysis of the potential influences of MRI scanners on the data obtained in this study.

Table S3. Mean values and standard deviations (STD) of $\mathrm{R} 2 \mathrm{t}^{*}$ distributions for three groups in Dark Matter $\left(\mathrm{R} 2 \mathrm{t}^{*}<5.8 \mathrm{~s}^{-1}\right)$, and Viable Tissue $\left(\mathrm{R} 2 \mathrm{t}^{*}>5.8 \mathrm{~s}^{-1}\right)$.

\section{References}

[1] Association As (2018) 2018 Alzheimer's disease facts and figures. Alzheimer's \& Dementia 14, 367429.

[2] Jack CR, Jr., Knopman DS, Jagust WJ, Shaw LM, Aisen PS, Weiner MW, Petersen RC, Trojanowski JQ (2010) Hypothetical model of dynamic biomarkers of the Alzheimer's pathological cascade. Lancet Neurol 9, 119-128.

[3] Bateman RJ, Xiong C, Benzinger TL, Fagan AM, Goate A, Fox NC, Marcus DS, Cairns NJ, Xie X, Blazey TM, Holtzman DM, Santacruz A, Buckles V, Oliver A, Moulder K, Aisen PS, Ghetti B, Klunk WE, McDade E, Martins RN, Masters CL, Mayeux R, Ringman JM, Rossor MN, Schofield PR, Sperling RA, Salloway S, Morris JC, Dominantly Inherited Alzheimer N (2012) Clinical and biomarker changes in dominantly inherited Alzheimer's disease. N Engl J Med 367, 795-804.

[4] Benzinger TL, Blazey T, Jack CR, Jr., Koeppe RA, Su Y, Xiong C, Raichle ME, Snyder AZ, Ances BM, Bateman RJ, Cairns NJ, Fagan AM, Goate A, Marcus DS, Aisen PS, Christensen JJ, Ercole L, Hornbeck RC, Farrar AM, Aldea P, Jasielec MS, Owen CJ, Xie X, Mayeux R, Brickman A, McDade E, Klunk W, Mathis CA, Ringman J, Thompson PM, Ghetti B, Saykin AJ, Sperling RA, Johnson KA, Salloway S, Correia S, Schofield PR, Masters CL, Rowe C, Villemagne VL, Martins R, Ourselin S, Rossor MN, Fox NC, Cash DM, Weiner MW, Holtzman DM, Buckles VD, Moulder K, Morris JC (2013) Regional variability of imaging biomarkers in autosomal dominant Alzheimer's disease. Proc Natl Acad Sci U S A 110, E4502-4509.

[5] Sperling RA, Aisen PS, Beckett LA, Bennett DA, Craft S, Fagan AM, Iwatsubo T, Jack CR, Jr., Kaye J, Montine TJ, Park DC, Reiman EM, Rowe CC, Siemers E, Stern Y, Yaffe K, Carrillo MC, Thies B, Morrison-Bogorad M, Wagster MV, Phelps CH (2011) Toward defining the preclinical stages of Alzheimer's disease: recommendations from the National Institute on Aging-Alzheimer's Association workgroups on diagnostic guidelines for Alzheimer's disease. Alzheimers Dement 7, 280-292.

[6] Long JM, Holtzman DM (2019) Alzheimer disease: an update on pathobiology and treatment strategies. Cell.

[7] Jack CR, Petersen RC, Xu YC, O’Brien PC, Smith GE, Ivnik RJ, Boeve BF, Waring SC, Tangalos EG, Kokmen E (1999) Prediction of AD with MRI-based hippocampal volume in mild cognitive impairment. Neurology 52, 1397-1397. 
medRxiv preprint doi: https://doi.org/10.1101/2021.04.27.21256098; this version posted April 29, 2021. The copyright holder for this preprint (which was not certified by peer review) is the author/funder, who has granted medRxiv a license to display the preprint in perpetuity.

All rights reserved. No reuse allowed without permission.

[8] Jack CR, Petersen RC, O'brien PC, Tangalos EG (1992) MR-based hippocampal volumetry in the diagnosis of Alzheimer's disease. Neurology 42, 183-183.

[9] Jack C, Petersen RC, Xu Y, O'brien P, Smith G, Ivnik R, Boeve BF, Tangalos EG, Kokmen E (2000) Rates of hippocampal atrophy correlate with change in clinical status in aging and AD. Neurology 55, 484-490.

[10] Kesslak JP, Nalcioglu O, Cotman CW (1991) Quantification of magnetic resonance scans for hippocampal and parahippocampal atrophy in Alzheimer's disease. Neurology 41, 51-51.

[11] Duvernoy HM (2005) The human hippocampus: functional anatomy, vascularization and serial sections with MRI, Springer Science \& Business Media.

[12] Braak H, Braak E (1991) Neuropathological stageing of Alzheimer-related changes. Acta neuropathologica 82, 239-259.

[13] Bobinski M, Wegiel J, Tarnawski M, Bobinski M, Reisberg B, De Leon MJ, Miller DC, Wisniewski HM (1997) Relationships between regional neuronal loss and neurofibrillary changes in the hippocampal formation and duration and severity of Alzheimer disease. Journal of Neuropathology \& Experimental Neurology 56, 414-420.

[14] Maruszak A, Thuret S (2014) Why looking at the whole hippocampus is not enough-a critical role for anteroposterior axis, subfield and activation analyses to enhance predictive value of hippocampal changes for Alzheimer's disease diagnosis. Frontiers in cellular neuroscience 8, 95.

[15] Mueller SG, Weiner MW (2009) Selective effect of age, Apo e4, and Alzheimer's disease on hippocampal subfields. Hippocampus 19, 558-564.

[16] Giuliano A, Donatelli G, Cosottini M, Tosetti M, Retico A, Fantacci ME (2017) H ippocampal subfields at ultra high field MRI: $\mathrm{A} n$ overview of segmentation and measurement methods. Hippocampus 27, 481-494.

[17] La C, Linortner P, Bernstein JD, Cruadhlaoich MAU, Fenesy M, Deutsch GK, Rutt BK, Tian L, Wagner $A D$, Zeineh M (2019) Hippocampal CA1 subfield predicts episodic memory impairment in Parkinson's disease. Neurolmage: Clinical 23, 101824.

[18] Haukvik UK, Tamnes CK, Söderman E, Agartz I (2018) Neuroimaging hippocampal subfields in schizophrenia and bipolar disorder: a systematic review and meta-analysis. Journal of psychiatric research 104, 217-226.

[19] Wisse LE, Biessels GJ, Heringa SM, Kuijf HJ, Luijten PR, Geerlings MI, Group UVCIVS (2014) Hippocampal subfield volumes at 7T in early Alzheimer's disease and normal aging. Neurobiology of aging 35, 2039-2045.

[20] Zheng F, Cui D, Zhang L, Zhang S, Zhao Y, Liu X, Liu C, Li Z, Zhang D, Shi L (2018) The volume of hippocampal subfields in relation to decline of memory recall across the adult lifespan. Frontiers in aging neuroscience 10, 320.

[21] Parker TD, Slattery CF, Yong KX, Nicholas JM, Paterson RW, Foulkes AJ, Malone IB, Thomas DL, Cash DM, Crutch SJ (2019) Differences in hippocampal subfield volume are seen in phenotypic variants of early onset Alzheimer's disease. Neurolmage: Clinical 21, 101632.

[22] La Joie R, Perrotin A, De La Sayette V, Egret S, Doeuvre L, Belliard S, Eustache F, Desgranges B, Chételat G (2013) Hippocampal subfield volumetry in mild cognitive impairment, Alzheimer's disease and semantic dementia. Neurolmage: Clinical 3, 155-162. 
medRxiv preprint doi: https://doi.org/10.1101/2021.04.27.21256098; this version posted April 29, 2021. The copyright holder for this preprint (which was not certified by peer review) is the author/funder, who has granted medRxiv a license to display the preprint in perpetuity.

All rights reserved. No reuse allowed without permission.

[23] Bastos-Leite AnJ, van der Flier WM, van Straaten EC, Staekenborg SS, Scheltens P, Barkhof F (2007) The contribution of medial temporal lobe atrophy and vascular pathology to cognitive impairment in vascular dementia. Stroke 38, 3182-3185.

[24] Jack CR, Bennett DA, Blennow K, Carrillo MC, Feldman HH, Frisoni GB, Hampel H, Jagust WJ, Johnson KA, Knopman DS, Petersen RC, Scheltens P, Sperling RA, Dubois B (2016) A/T/N: An unbiased descriptive classification scheme for Alzheimer disease biomarkers. Neurology 87, 539547.

[25] Price JL, Ko Al, Wade MJ, Tsou SK, McKeel DW, Morris JC (2001) Neuron number in the entorhinal cortex and CA1 in preclinical Alzheimer disease. Archives of neurology 58, 1395-1402.

[26] Mecca AP, Chen M-K, O'Dell RS, Naganawa M, Toyonaga T, Godek TA, Harris JE, Bartlett HH, Zhao W, Nabulsi NB, Wyk BCV, Varma P, Arnsten AFT, Huang Y, Carson RE, van Dyck CH (2020) In vivo measurement of widespread synaptic loss in Alzheimer's disease with SV2A PET. Alzheimer's \& Dementia 16, 974-982.

[27] Gomez-Isla T, Price JL, McKeel DW, Jr., Morris JC, Growdon JH, Hyman BT (1996) Profound loss of layer II entorhinal cortex neurons occurs in very mild Alzheimer's disease. J Neurosci 16, 44914500.

[28] Terry RD, Masliah E, Salmon DP, Butters N, DeTeresa R, Hill R, Hansen LA, Katzman R (1991) Physical basis of cognitive alterations in Alzheimer's disease: synapse loss is the major correlate of cognitive impairment. Ann Neurol 30, 572-580.

[29] Selkoe DJ (2002) Alzheimer's disease is a synaptic failure. Science 298, 789-791.

[30] West MJ, Coleman PD, Flood DG, Troncoso JC (1994) Differences in the pattern of hippocampal neuronal loss in normal ageing and Alzheimer's disease. The Lancet 344, 769-772.

[31] Ulrich X, Yablonskiy DA (2016) Separation of cellular and BOLD contributions to T2* signal relaxation. Magnetic resonance in medicine 75, 606-615.

[32] Wen J, Goyal MS, Astafiev SV, Raichle ME, Yablonskiy DA (2018) Genetically defined cellular correlates of the baseline brain MRI signal. Proceedings of the National Academy of Sciences 115, E9727-E9736.

[33] Ogawa S, Lee TM, Kay AR, Tank DW (1990) Brain magnetic resonance imaging with contrast dependent on blood oxygenation. Proc Natl Acad Sci U S A 87, 9868-9872.

[34] Yablonskiy DA, Haacke EM (1994) Theory of NMR signal behavior in magnetically inhomogeneous tissues: the static dephasing regime. Magn Reson Med 32, 749-763.

[35] Yablonskiy DA (1998) Quantitation of intrinsic magnetic susceptibility-related effects in a tissue matrix. Phantom study. Magn Reson Med 39, 417-428.

[36] He X, Zhu M, Yablonskiy DA (2008) Validation of oxygen extraction fraction measurement by qBOLD technique. Magn Reson Med 60, 882-888.

[37] Peng GP, Feng Z, He FP, Chen ZQ, Liu XY, Liu P, Luo BY (2015) Correlation of hippocampal volume and cognitive performances in patients with either mild cognitive impairment or Alzheimer's disease. CNS neuroscience \& therapeutics 21, 15-22.

[38] Carlesimo GA, Piras F, Orfei MD, lorio M, Caltagirone C, Spalletta G (2015) Atrophy of presubiculum and subiculum is the earliest hippocampal anatomical marker of Alzheimer's disease. Alzheimer's \& Dementia: Diagnosis, Assessment \& Disease Monitoring 1, 24-32. 
medRxiv preprint doi: https://doi.org/10.1101/2021.04.27.21256098; this version posted April 29, 2021. The copyright holder for this preprint (which was not certified by peer review) is the author/funder, who has granted medRxiv a license to display the preprint in perpetuity.

All rights reserved. No reuse allowed without permission.

[39] Izzo J, Andreassen OA, Westlye LT, van der Meer D (2020) The association between hippocampal subfield volumes in mild cognitive impairment and conversion to Alzheimer's disease. Brain Research 1728, 146591.

[40] Kerchner G, Hess C, Hammond-Rosenbluth K, Xu D, Rabinovici G, Kelley D, Vigneron D, Nelson S, Miller B (2010) Hippocampal CA1 apical neuropil atrophy in mild Alzheimer disease visualized with 7-T MRI. Neurology 75, 1381-1387.

[41] van der Flier WM, van Straaten EC, Barkhof F, Ferro J, Pantoni L, Basile A-M, Inzitari D, Erkinjuntti T, Wahlund LO, Rostrup E (2005) Medial temporal lobe atrophy and white matter hyperintensities are associated with mild cognitive deficits in non-disabled elderly people: the LADIS study. Journal of Neurology, Neurosurgery \& Psychiatry 76, 1497-1500.

[42] Kantarci K, Clifford R. Jack J, Xu YC, Campeau NG, O'Brien PC, Smith GE, Ivnik RJ, Boeve BF, Kokmen E, Tangalos EG, Petersen RC (2001) Mild Cognitive Impairment and Alzheimer Disease: Regional Diffusivity of Water. 219, 101-107.

[43] Mormino EC, Kluth JT, Madison CM, Rabinovici GD, Baker SL, Miller BL, Koeppe RA, Mathis CA, Weiner MW, Jagust WJ, Initiative* tAsDN (2008) Episodic memory loss is related to hippocampalmediated $\beta$-amyloid deposition in elderly subjects. Brain 132, 1310-1323.

[44] O'Shea A, Cohen R, Porges EC, Nissim NR, Woods AJ (2016) Cognitive aging and the hippocampus in older adults. Frontiers in aging neuroscience 8, 298.

[45] Braak H, Thal DR, Ghebremedhin E, Del Tredici K (2011) Stages of the pathologic process in Alzheimer disease: age categories from 1 to 100 years. J Neuropathol Exp Neurol 70, 960-969.

[46] Marquez F, Yassa MA (2019) Neuroimaging Biomarkers for Alzheimer's Disease. Mol Neurodegener 14, 21.

[47] Raz N, Lindenberger U, Rodrigue KM, Kennedy KM, Head D, Williamson A, Dahle C, Gerstorf D, Acker JD (2005) Regional brain changes in aging healthy adults: general trends, individual differences and modifiers. Cerebral cortex 15, 1676-1689.

[48] Rosen AC, Prull MW, Gabrieli JD, Stoub T, O'Hara R, Friedman L, Yesavage JA, deToledo-Morrell L (2003) Differential associations between entorhinal and hippocampal volumes and memory performance in older adults. Behav Neurosci 117, 1150-1160.

[49] Zhao Y, Raichle ME, Wen J, Benzinger TL, Fagan AM, Hassenstab J, Vlassenko AG, Luo J, Cairns NJ, Christensen JJ (2017) In vivo detection of microstructural correlates of brain pathology in preclinical and early Alzheimer disease with magnetic resonance imaging. Neuroimage 148, 296304.

[50] Wearn AR, Nurdal V, Saunders-Jennings E, Knight MJ, Isotalus HK, Dillon S, Tsivos D, Kauppinen RA, Coulthard EJ (2020) T2 heterogeneity: a novel marker of microstructural integrity associated with cognitive decline in people with mild cognitive impairment. Alzheimer's Research \& Therapy 12, 105.

[51] Vogt NM, Hunt JF, Adluru N, Dean DC, Johnson SC, Asthana S, Yu J-PJ, Alexander AL, Bendlin BB (2019) Cortical microstructural alterations in mild cognitive impairment and Alzheimer's disease dementia. Cerebral Cortex.

[52] Ayton S, Fazlollahi A, Bourgeat P, Raniga P, Ng A, Lim YY, Diouf I, Farquharson S, Fripp J, Ames D (2017) Cerebral quantitative susceptibility mapping predicts amyloid- $\beta$-related cognitive decline. Brain 140, 2112-2119. 
medRxiv preprint doi: https://doi.org/10.1101/2021.04.27.21256098; this version posted April 29, 2021. The copyright holder for this preprint (which was not certified by peer review) is the author/funder, who has granted medRxiv a license to display the preprint in perpetuity.

All rights reserved. No reuse allowed without permission.

[53] Schmierer K, McDowell A, Petrova N, Carassiti D, Thomas DL, Miquel ME (2018) Quantifying multiple sclerosis pathology in post mortem spinal cord using MRI. Neuroimage 182, 251-258.

[54] Bittner DM, Heinze H-J, Kaufmann J (2013) Association of 1H-MR spectroscopy and cerebrospinal fluid biomarkers in Alzheimer's disease: diverging behavior at three different brain regions. Journal of Alzheimer's Disease 36, 155-163.

[55] Zhao Y, Wen J, Cross AH, Yablonskiy DA (2016) On the relationship between cellular and hemodynamic properties of the human brain cortex throughout adult lifespan. Neuroimage 133, 417-429.

[56] Bouras C, Hof PR, Morrison JH (1993) Neurofibrillary tangle densities in the hippocampal formation in a non-demented population define subgroups of patients with differential early pathologic changes. Neuroscience letters 153, 131-135.

[57] Sonnen JA, Santa Cruz K, Hemmy LS, Woltjer R, Leverenz JB, Montine KS, Jack CR, Kaye J, Lim K, Larson EB (2011) Ecology of the aging human brain. Archives of neurology 68, 1049-1056.

[58] Crary JF, Trojanowski JQ, Schneider JA, Abisambra JF, Abner EL, Alafuzoff I, Arnold SE, Attems J, Beach TG, Bigio EH (2014) Primary age-related tauopathy (PART): a common pathology associated with human aging. Acta neuropathologica 128, 755-766.

[59] Guillozet AL, Weintraub S, Mash DC, Mesulam MM (2003) Neurofibrillary tangles, amyloid, and memory in aging and mild cognitive impairment. Archives of neurology 60, 729-736.

[60] Chawalparit O, Wontaneeporn N, Muangpaisan W, Thientunyakit T, Charnchaowanish P (2019) MRI Hippocampal Subfield Volume Analysis: Comparison between Alzheimer's Disease, Mild Cognitive Impairment, and Normal Aging Subjects in an Amyloid PET Project. J Alzheimers Dis Parkinsonism 9, 2161-0460.1000459.

[61] Zhao W, Wang X, Yin C, He M, Li S, Han Y (2019) Trajectories of The Hippocampal Subfields Atrophy in the Alzheimer's Disease: A Structural Imaging Study. Frontiers in Neuroinformatics 13, 13.

[62] Apostolova LG, Green AE, Babakchanian S, Hwang KS, Chou Y-Y, Toga AW, Thompson PM (2012) Hippocampal atrophy and ventricular enlargement in normal aging, mild cognitive impairment and Alzheimer's disease. Alzheimer disease and associated disorders 26, 17.

[63] Blanken AE, Hurtz S, Zarow C, Biado K, Honarpisheh H, Somme J, Brook J, Tung S, Kraft E, Lo D (2017) Associations between hippocampal morphometry and neuropathologic markers of Alzheimer's disease using 7 T MRI. Neurolmage: Clinical 15, 56-61.

[64] Iglesias JE, Augustinack JC, Nguyen K, Player CM, Player A, Wright M, Roy N, Frosch MP, McKee AC, Wald LL (2015) A computational atlas of the hippocampal formation using ex vivo, ultra-high resolution MRI: application to adaptive segmentation of in vivo MRI. Neuroimage 115, 117-137.

[65] Akram A, Christoffel D, Rocher AB, Bouras C, Kövari E, Perl DP, Morrison JH, Herrmann FR, Haroutunian V, Giannakopoulos P (2008) Stereologic estimates of total spinophilinimmunoreactive spine number in area 9 and the CA1 field: relationship with the progression of Alzheimer's disease. Neurobiology of aging 29, 1296-1307.

[66] Scheff S, Price D, Schmitt F, DeKosky S, Mufson E (2007) Synaptic alterations in CA1 in mild Alzheimer disease and mild cognitive impairment. Neurology 68, 1501-1508.

[67] Helboe L, Egebjerg J, Barkholt P, Volbracht C (2017) Early depletion of CA1 neurons and late neurodegeneration in a mouse tauopathy model. Brain research 1665, 22-35. 
medRxiv preprint doi: https://doi.org/10.1101/2021.04.27.21256098; this version posted April 29, 2021. The copyright holder for this preprint (which was not certified by peer review) is the author/funder, who has granted medRxiv a license to display the preprint in perpetuity.

All rights reserved. No reuse allowed without permission.

[68] Grober E, Hall C, Sanders AE, Lipton RB (2008) Free and cued selective reminding distinguishes Alzheimer's disease from vascular dementia. Journal of the American Geriatrics Society 56, 944.

[69] Grober E, Sanders AE, Hall C, Lipton RB (2010) Free and cued selective reminding identifies very mild dementia in primary care. Alzheimer disease and associated disorders 24, 284.

[70] Grober E, Veroff AE, Lipton RB (2018) Temporal unfolding of declining episodic memory on the Free and Cued Selective Reminding Test in the predementia phase of Alzheimer's disease: Implications for clinical trials. Alzheimer's \& Dementia: Diagnosis, Assessment \& Disease Monitoring 10, 161-171.

[71] Gorbach T, Pudas S, Lundquist A, Orädd G, Josefsson M, Salami A, de Luna X, Nyberg L (2017) Longitudinal association between hippocampus atrophy and episodic-memory decline. Neurobiology of aging 51, 167-176.

[72] Hett K, Ta V-T, Catheline G, Tourdias T, Manjón JV, Coupé P, Weiner MW, Aisen P, Petersen R, Jack CR, Jagust W, Trojanowki JQ, Toga AW, Beckett L, Green RC, Saykin AJ, Morris J, Shaw LM, Khachaturian Z, Sorensen G, Carrillo M, Kuller L, Raichle M, Paul S, Davies P, Fillit H, Hefti F, Holtzman D, Mesulam MM, Potter W, Snyder P, Montine T, Thomas RG, Donohue M, Walter S, Sather T, Jiminez G, Balasubramanian AB, Mason J, Sim I, Harvey D, Bernstein M, Fox N, Thompson P, Schuff N, DeCarli C, Borowski B, Gunter J, Senjem M, Vemuri P, Jones D, Kantarci K, Ward C, Koeppe RA, Foster N, Reiman EM, Chen K, Mathis C, Landau S, Cairns NJ, Householder E, TaylorReinwald L, Lee V, Korecka M, Figurski M, Crawford K, Neu S, Foroud TM, Potkin S, Shen L, Faber K, Kim S, Nho K, Thal L, Frank R, Hsiao J, Kaye J, Quinn J, Silbert L, Lind B, Carter R, Dolen S, Ances $B$, Carroll M, Creech ML, Franklin E, Mintun MA, Schneider S, Oliver A, Schneider LS, Pawluczyk S, Beccera M, Teodoro L, Spann BM, Brewer J, Vanderswag H, Fleisher A, Marson D, Griffith R, Clark D, Geldmacher D, Brockington J, Roberson E, Love MN, Heidebrink JL, Lord JL, Mason SS, Albers CS, Knopman D, Johnson K, Grossman H, Mitsis E, Shah RC, deToledo-Morrell L, Doody RS, Villanueva-Meyer J, Chowdhury M, Rountree S, Dang M, Duara R, Varon D, Greig MT, Roberts $P$, Stern Y, Honig LS, Bell KL, Albert M, Onyike C, D'Agostino D, Kielb S, Galvin JE, Cerbone B, Michel CA, Pogorelec DM, Rusinek H, de Leon MJ, Glodzik L, De Santi S, Womack K, Mathews D, Quiceno M, Doraiswamy PM, Petrella JR, Borges-Neto S, Wong TZ, Coleman E, Levey Al, Lah JJ, Cella JS, Burns JM, Swerdlow RH, Brooks WM, Arnold SE, Karlawish JH, Wolk D, Clark CM, Apostolova L, Tingus K, Woo E, Silverman DHS, Lu PH, Bartzokis G, Smith CD, Jicha G, Hardy P, Sinha P, Oates E, Conrad G, Graff-Radford NR, Parfitt F, Kendall T, Johnson H, Lopez OL, Oakley M, Simpson DM, Farlow MR, Hake AM, Matthews BR, Brosch JR, Herring S, Hunt C, Porsteinsson AP, Goldstein BS, Martin K, Makino KM, Ismail MS, Brand C, Mulnard RA, Thai G, Mc-Adams-Ortiz C, van Dyck CH, Carson RE, MacAvoy MG, Varma P, Chertkow H, Bergman H, Hosein C, Black S, Stefanovic B, Caldwell C, Hsiung G-YR, Feldman H, Mudge B, Assaly M, Finger E, Pasternack S, Rachisky I, Trost D, Kertesz A, Bernick C, Munic D, Lipowski K, Weintraub MAS, Bonakdarpour B, Kerwin D, Wu CK, Johnson N, Sadowsky C, Villena T, Turner RS, Johnson K, Reynolds B, Sperling RA, Johnson KA, Marshall G, Yesavage J, Taylor JL, Lane B, Rosen A, Tinklenberg J, Sabbagh MN, Belden CM, Jacobson SA, Sirrel SA, Kowall N, Killiany R, Budson AE, Norbash A, Johnson PL, Obisesan TO, Wolday S, Allard J, Lerner A, Ogrocki P, Tatsuoka C, Fatica P, Fletcher E, Maillard P, Olichney J, Carmichael O, Kittur S, Borrie M, Lee TY, Bartha R, Johnson S, Asthana S, Carlsson CM, Preda A, Nguyen D, Tariot $P$, Burke A, Trncic N, Fleisher A, Reeder S, Bates V, Capote H, Rainka M, Scharre DW, Kataki M, Adeli A, Zimmerman EA, Celmins D, Brown AD, Pearlson GD, Blank K, Anderson K, Flashman LA, Seltzer M, Hynes ML, Santulli RB, Sink KM, Gordineer L, Williamson JD, Garg P, Watkins F, Ott BR, Querfurth H, Tremont G, Salloway S, Malloy P, Correia S, Rosen HJ, Miller BL, Perry D, Mintzer J, Spicer K, Bachman D, Finger E, Pasternak S, Alzheimer's Disease Neuroimaging 
medRxiv preprint doi: https://doi.org/10.1101/2021.04.27.21256098; this version posted April 29, 2021. The copyright holder for this preprint (which was not certified by peer review) is the author/funder, who has granted medRxiv a license to display the preprint in perpetuity.

All rights reserved. No reuse allowed without permission.

I (2019) Multimodal Hippocampal Subfield Grading For Alzheimer's Disease Classification. Scientific Reports 9, 13845.

[73] Torop M, Kothapalli S, Sun Y, Liu J, Kahali S, Yablonskiy DA, Kamilov US (2020) Deep learning using a biophysical model for robust and accelerated reconstruction of quantitative, artifact-free and denoised R 2 * images. Magn Reson Med 84, 2932-2942.

[74] Morris JC (1997) Clinical dementia rating: a reliable and valid diagnostic and staging measure for dementia of the Alzheimer type. International psychogeriatrics 9, 173-176.

[75] Morris JC (1993) The Clinical Dementia Rating (CDR): current version and scoring rules. Neurology.

[76] Grober E, Buschke H, Crystal H, Bang S, Dresner R (1988) Screening for dementia by memory testing. Neurology 38, 900-900.

[77] Armitage SG (1946) An analysis of certain psychological tests used for the evaluation of brain injury. Psychological monographs 60, i.

[78] Goodglass H, Kaplan E (1983) Boston diagnostic aphasia examination booklet, Lea \& Febiger.

[79] Scale-Third WDWM (1997) edition: Administration and scoring manual. San Antonio, TX: The Psychological Corporation.

[80] Fagan AM, Mintun MA, Mach RH, Lee SY, Dence CS, Shah AR, LaRossa GN, Spinner ML, Klunk WE, Mathis CA (2006) Inverse relation between in vivo amyloid imaging load and cerebrospinal fluid A 442 in humans. Annals of neurology 59, 512-519.

[81] Morris JC, Roe CM, Grant EA, Head D, Storandt M, Goate AM, Fagan AM, Holtzman DM, Mintun MA (2009) Pittsburgh compound $B$ imaging and prediction of progression from cognitive normality to symptomatic Alzheimer disease. Arch Neurol 66, 1469-1475.

[82] Fagan AM, Roe CM, Xiong C, Mintun MA, Morris JC, Holtzman DM (2007) Cerebrospinal fluid tau/beta-amyloid(42) ratio as a prediction of cognitive decline in nondemented older adults. Arch Neurol 64, 343-349.

[83] Jack CR, Jr. (2020) Preclinical Alzheimer's disease: a valid concept. The Lancet Neurology 19, 31.

[84] Mugler III JP, Brookeman JR (1990) Three-dimensional magnetization-prepared rapid gradientecho imaging (3D MP RAGE). Magnetic Resonance in Medicine 15, 152-157.

[85] Wen J, Cross AH, Yablonskiy DA (2015) On the role of physiological fluctuations in quantitative gradient echo MRI: implications for GEPCI, QSM, and SWI. Magnetic resonance in medicine 73, 195-203.

[86] Quirk JD, Sukstanskii AL, Bretthorst GL, Yablonskiy DA (2009) Optimal decay rate constant estimates from phased array data utilizing joint Bayesian analysis. Journal of Magnetic Resonance 198, 49-56.

[87] Luo J, Jagadeesan BD, Cross AH, Yablonskiy DA (2012) Gradient echo plural contrast imagingsignal model and derived contrasts: T2*, T1, phase, SWI, T1f, FST2* and T2*-SWI. Neuroimage 60, 1073-1082.

[88] Yablonskiy DA, Haacke EM (1994) Theory of NMR signal behavior in magnetically inhomogeneous tissues: the static dephasing regime. Magnetic resonance in medicine 32, 749-763.

[89] Yablonskiy DA (1998) Quantitation of intrinsic magnetic susceptibility-related effects in a tissue matrix. Phantom study. Magnetic resonance in medicine 39, 417-428. 
medRxiv preprint doi: https://doi.org/10.1101/2021.04.27.21256098; this version posted April 29, 2021. The copyright holder for this preprint

(which was not certified by peer review) is the author/funder, who has granted medRxiv a license to display the preprint in perpetuity.

All rights reserved. No reuse allowed without permission.

[90] Yablonskiy DA, Sukstanskii AL, Luo J, Wang X (2013) Voxel spread function method for correction of magnetic field inhomogeneity effects in quantitative gradient-echo-based MRI. Magnetic resonance in medicine 70, 1283-1292.

[91] Wen J, Feiyan Zeng, Dmitriy Yablonskiy, Alexander Sukstansky, Ying Liu, Bin Cai, Yong Zhang, and Weifu Lv (2020) Fast library-driven approach for implementation of the voxel spread function technique for correcting magnetic field inhomogeneity artifacts. arXiv preprint arXiv 2001.

[92] Jenkinson M, Smith S (2001) A global optimisation method for robust affine registration of brain images. Medical image analysis 5, 143-156.

[93] Jenkinson M, Bannister P, Brady M, Smith S (2002) Improved optimization for the robust and accurate linear registration and motion correction of brain images. Neuroimage 17, 825-841.

Acknowledgments: The authors would like to thank Brian Gordon for helpful discussion and Erin Franklin for facilitating and coordinating histopathological evaluations.

Author contributions: Study design, MRI data analysis: S.K. and D.Y.; MRI data collection: S.K. and T.B.; PET data collection and analysis: T.B.; CSF data collection and analysis: A.F.; Interpretation of cognitive scores: A.A. and J.M.; MRI radiology read: M.G.; Neuropathology study design and analysis: R.P.; statistical analysis S.K., C.H., and D.Y.; manuscript writing: S.K., and D.Y. All authors critically contributed to this work at all stages of project execution and discussion. All authors provided critical comments during manuscript preparation and approved the final version.

Competing interests: The authors declare that they have no competing interests.

Data and materials availability: Data associated with this study are present in the paper or the Supplementary Materials. Any additional information can be supplied upon request. 
medRxiv preprint doi: https://doi.org/10.1101/2021.04.27.21256098; this version posted April 29, 2021. The copyright holder for this preprint

(which was not certified by peer review) is the author/funder, who has granted medRxiv a license to display the preprint in perpetuity.

All rights reserved. No reuse allowed without permission.

\section{Quantitative Gradient Echo MRI Identifies Dark Matter as a New Imaging Biomarker of Neurodegeneration that Precedes Tissue Atrophy in Early Alzheimer Disease}

\section{Supplementary Materials}

Figure S1. Correlation of individual neurocognitive tests with fraction of Dark Matter, volume of Viable Tissue, and Total Volume of the hippocampus.

Figure S2. Classification tree analysis using Dark Matter and Viable Tissue volume parameters.

Figure S3. Classification tree analysis using Dark Matter and Viable Tissue volume parameters with taking account of participant's age.

Figure S4. Classification tree analysis using Dark Matter and Viable Tissue volume parameters with taking account of participant's gender information.

Figure S5. Results of a classification-tree that was produced using hippocampal Total Volume variable as a predictor.

Figure S6. ROC-based comparisons of classification results based qGRE metrics versus commonly used tissue atrophy.

Figure S7. The choice of R2t* threshold for justifying the separation of Dark Matter volume from Viable tissue volume.

Table S1. Summary of mean neuronal count and Dark Matter measurements in five hippocampal subfields.

Table S2. Statistical analysis of the potential influences of MRI scanners on the data obtained in this study.

Table S3. Mean values and standard deviations (STD) of R2t* distributions for three groups in Dark Matter $\left(\mathrm{R} 2 \mathrm{t}^{*}<5.8 \mathrm{~s}^{-1}\right)$, and Viable Tissue $\left(\mathrm{R} 2 \mathrm{t}^{*}>5.8 \mathrm{~s}^{-1}\right)$. 

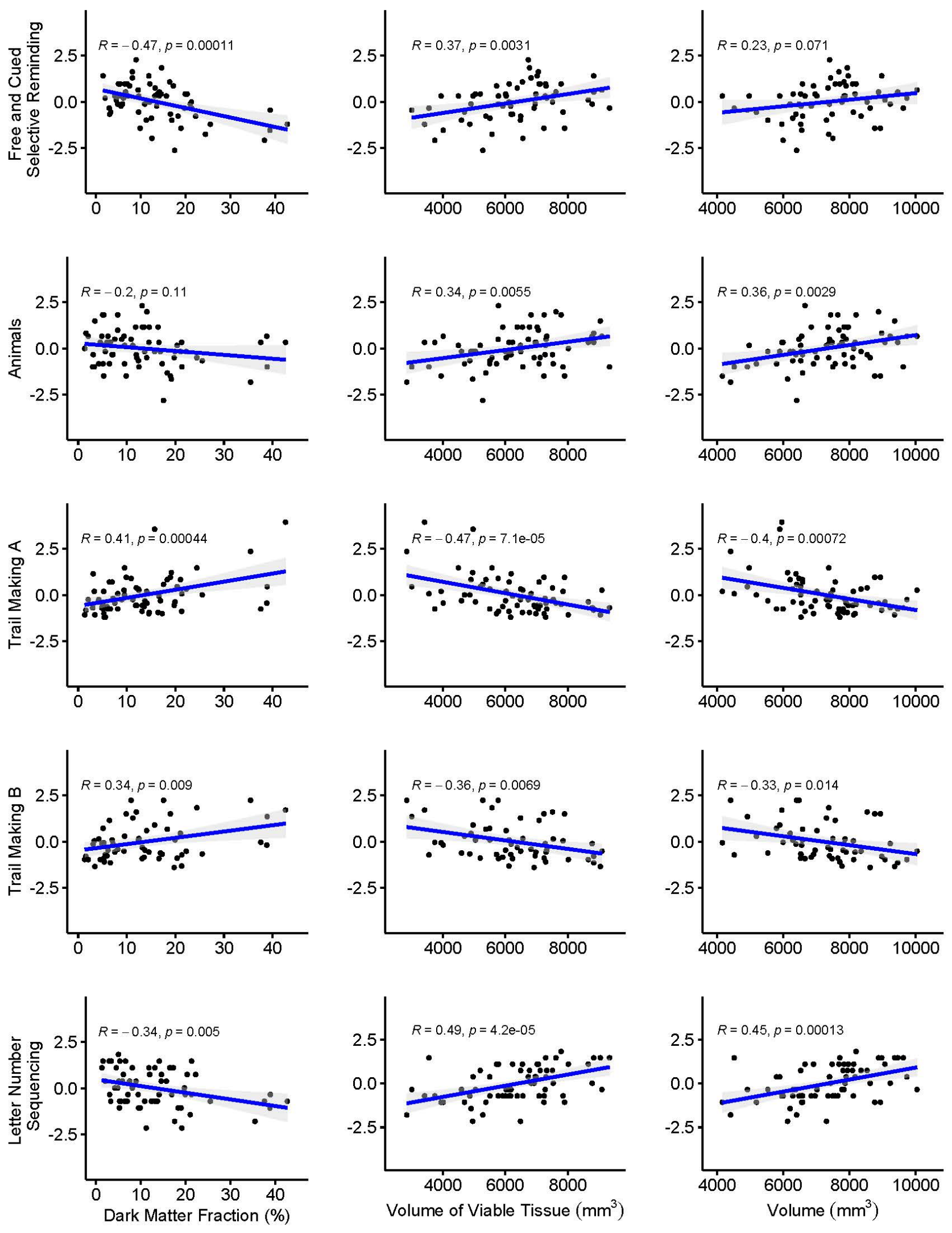

Figure S1. Correlation of individual neurocognitive tests with fraction of Dark Matter, volume of Viable Tissue, and Total Volume of the hippocampus. Each point represents an individual participant. 


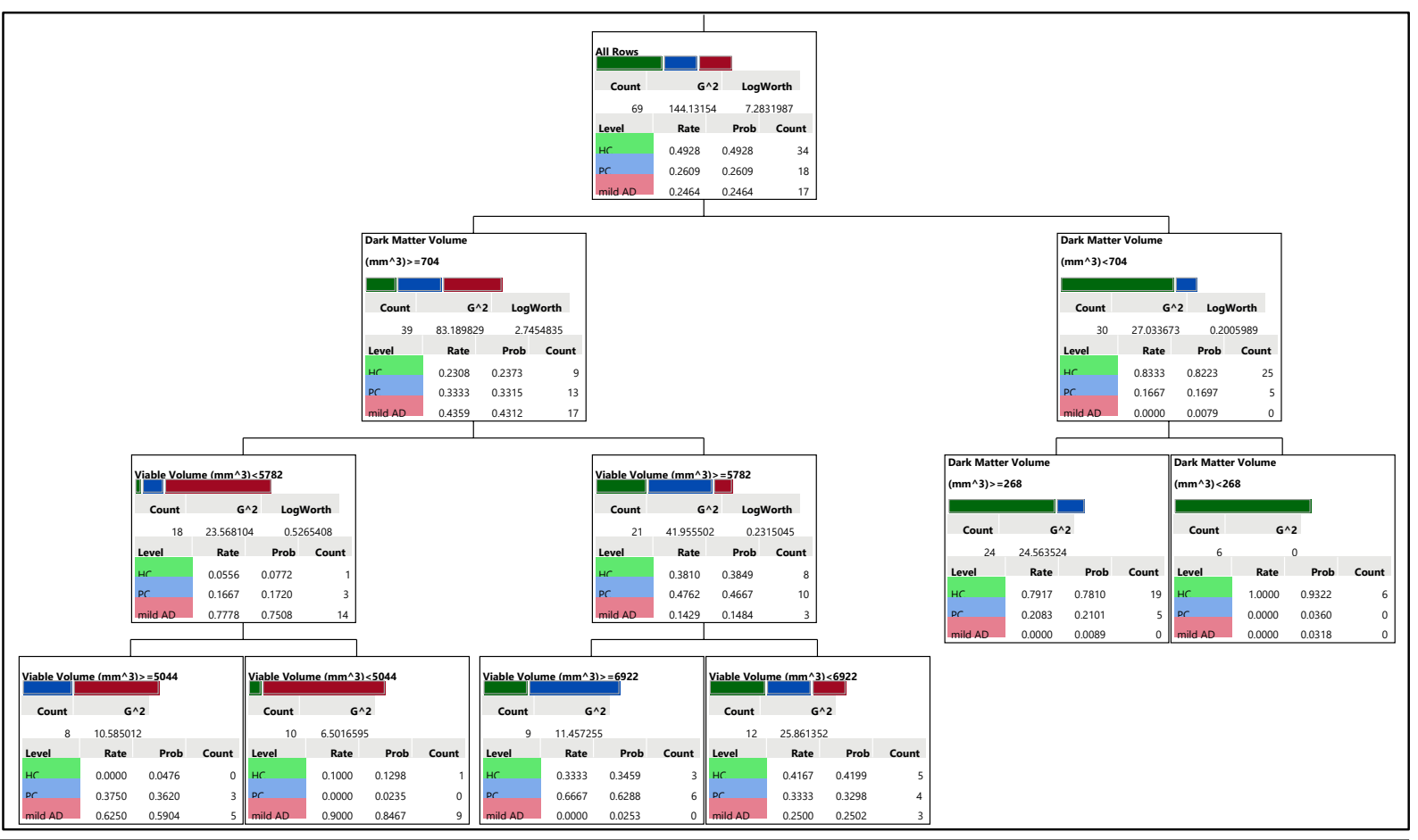

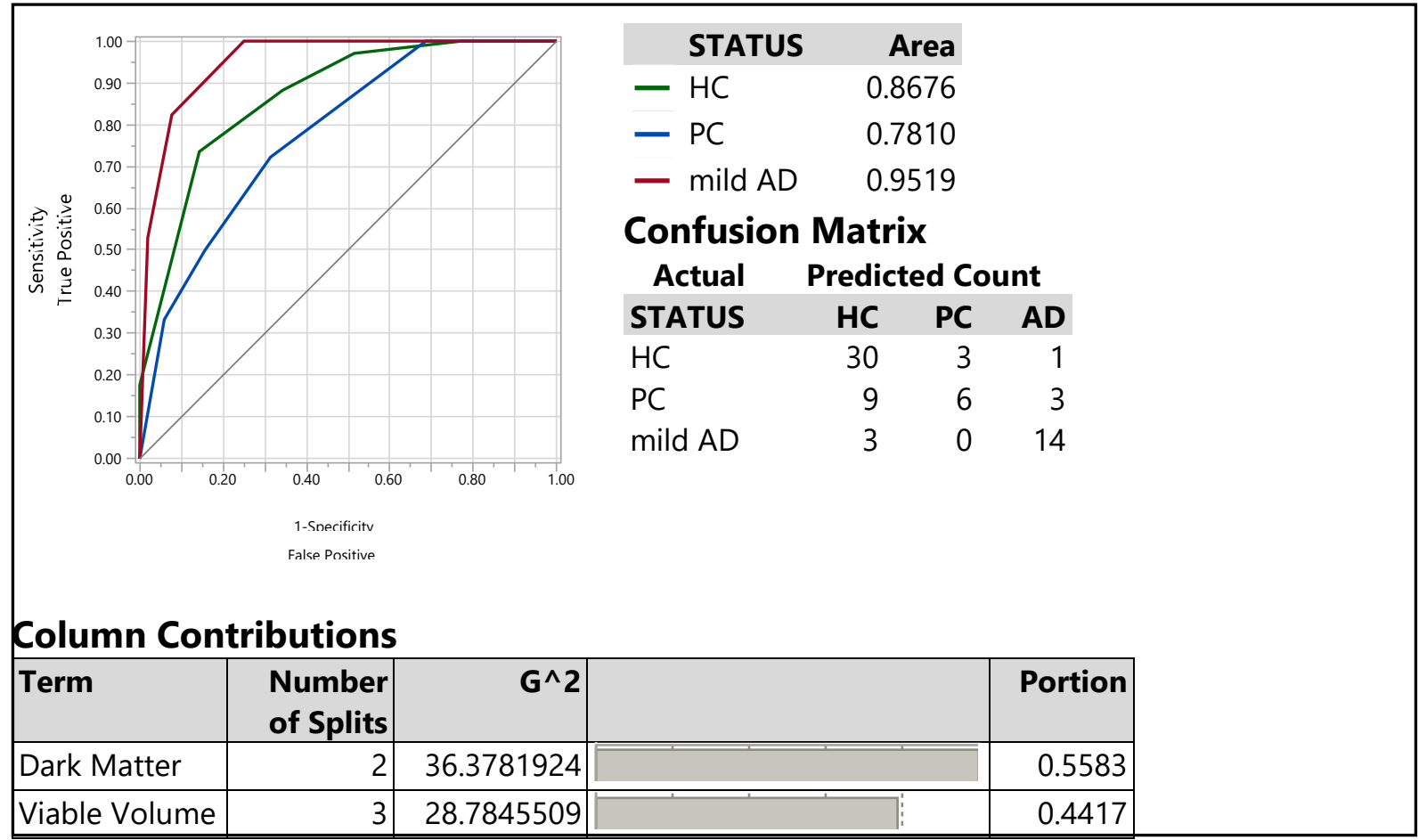

Figure S2. Results of a classification-tree that was produced using global hippocampal Dark Matter volume and Viable Tissue volume variables as predictors. The top panel presents the classification tree diagram with threshold's, middle panel presents receiver operating characteristic (ROC) curves and areas under the curves (AUCs), a confusion matrix, and bottom panel presents the contribution of variables in the classification of $\mathrm{HC}$, $\mathrm{PC}$, and $\mathrm{AD}$ groups. The confusion matrix presents the numbers of correct and incorrect classifications. 

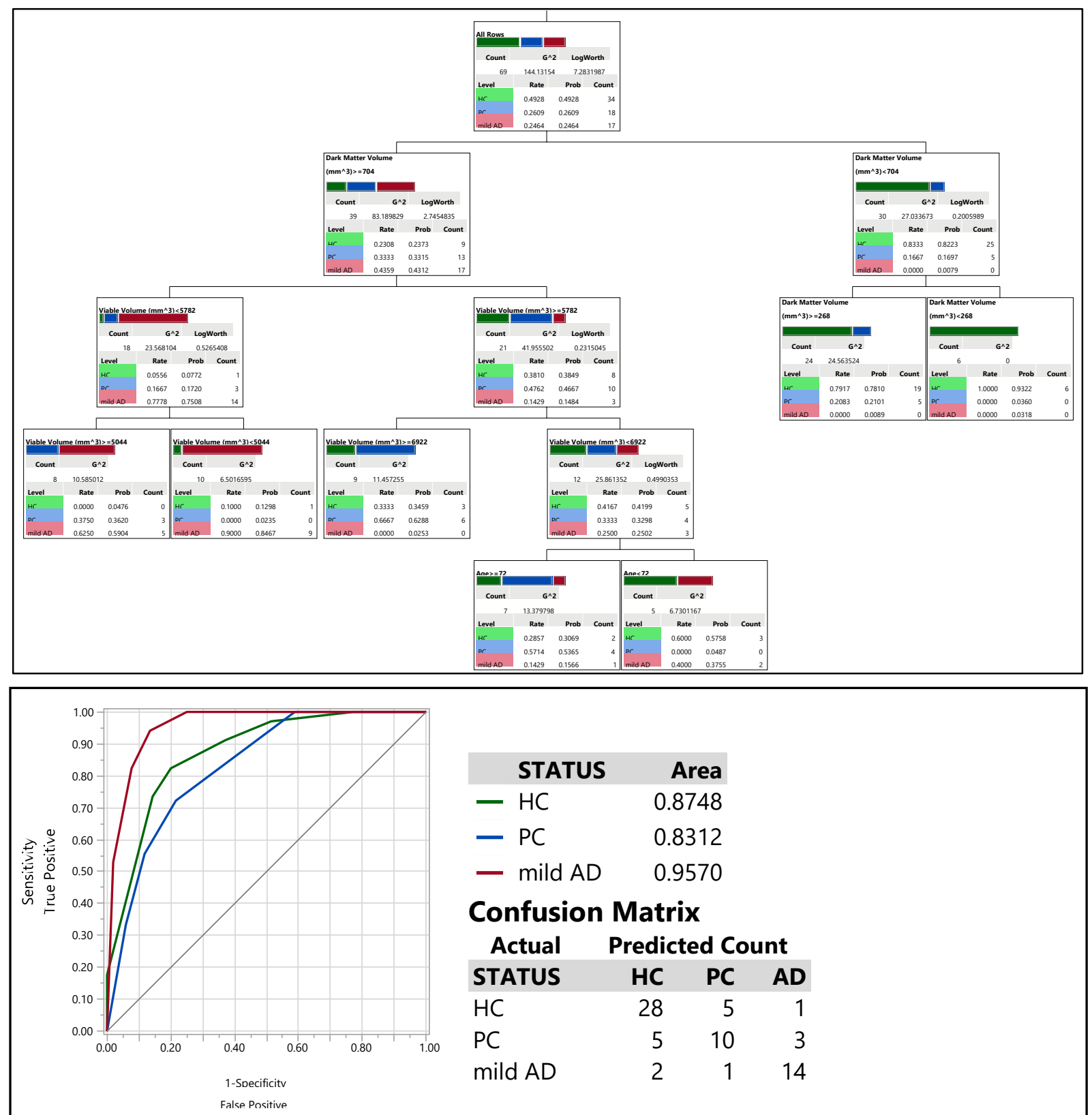

$\begin{array}{lr}\text { STATUS } & \text { Area } \\ - \text { HC } & 0.8748 \\ - \text { PC } & 0.8312 \\ - \text { mild AD } & 0.9570\end{array}$

\section{Column Contributions}

\begin{tabular}{|lrr|r|r} 
Term & $\begin{array}{r}\text { Number } \\
\text { of Splits }\end{array}$ & \multicolumn{1}{|c}{ G^2 } & Portion \\
Viable Volume & 2 & 36.3781924 & & \\
Dark Matter & 2 & 10.6888841 & & 0.5130 \\
Age & 1 & 5.7514367 & & 0.2190 \\
\hline
\end{tabular}

Figure S3. Results of a classification-tree that was produced using global hippocampal Dark Matter volume, Viable Tissue volume, and participant's age variables as predictors. The top panel presents the classification tree diagram with threshold's, middle panel presents receiver operating characteristic (ROC) curves and areas under the curves (AUCs), a confusion matrix, and bottom panel presents the contribution of variables in the classification of $\mathrm{HC}, \mathrm{PC}$, and $\mathrm{AD}$ groups. The confusion matrix presents the numbers of correct and incorrect classifications. 


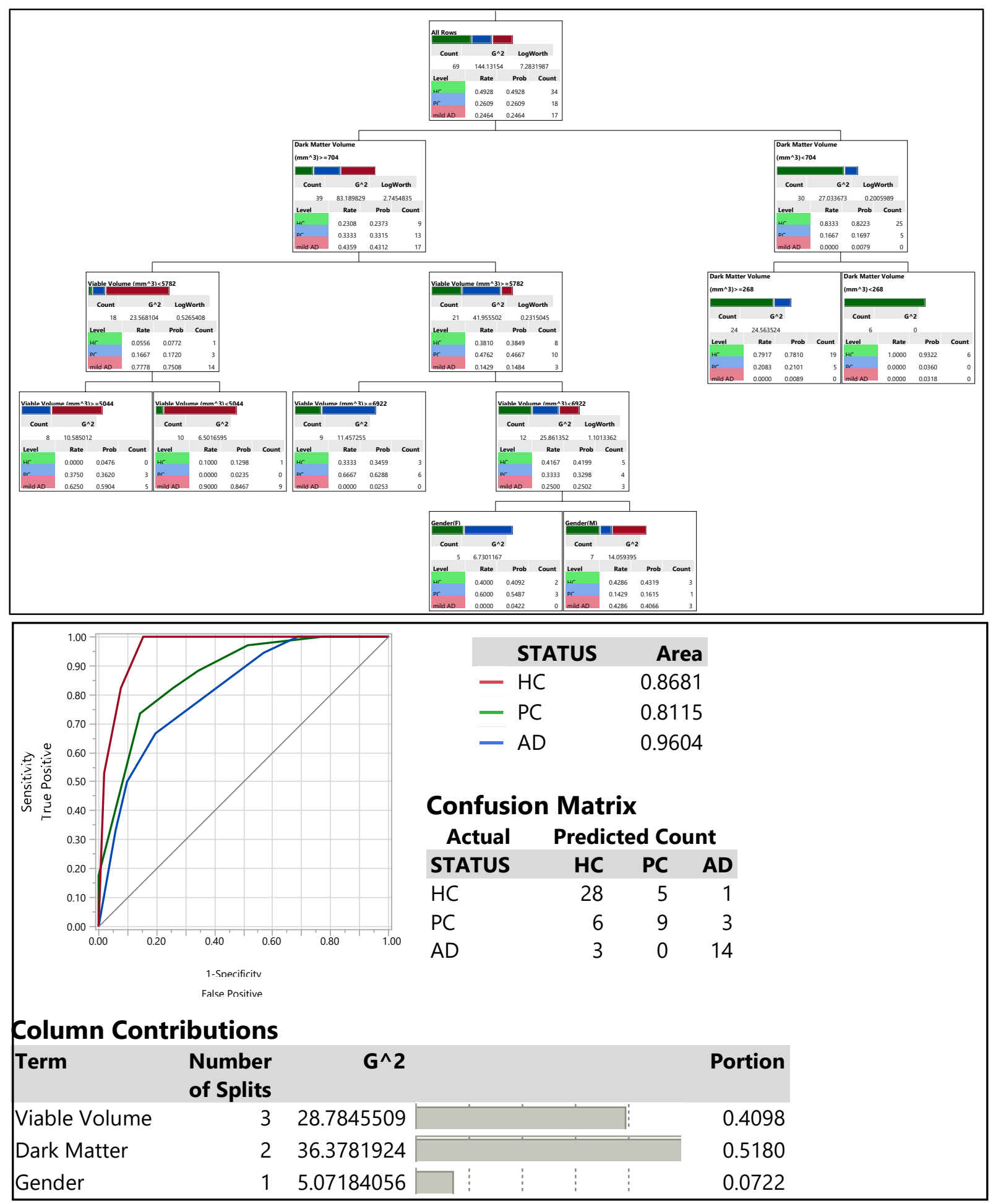

Figure S4. Results of a classification-tree that was produced using global hippocampal Dark Matter volume, Viable Tissue volume, and Gender variables as predictors. The top panel presents the classification tree diagram with threshold's, middle panel presents receiver operating characteristic (ROC) curves and areas under the curves (AUCs), a confusion matrix, and bottom panel presents the contribution of variables in the classification of $\mathrm{HC}$, $\mathrm{PC}$, and AD groups. The confusion matrix presents the numbers of correct and incorrect classifications. 
medRxiv preprint doi: https://doi.org/10.1101/2021.04.27.21256098; this version posted April 29, 2021. The copyright holder for this preprint (which was not certified by peer review) is the author/funder, who has granted medRxiv a license to display the preprint in perpetuity.

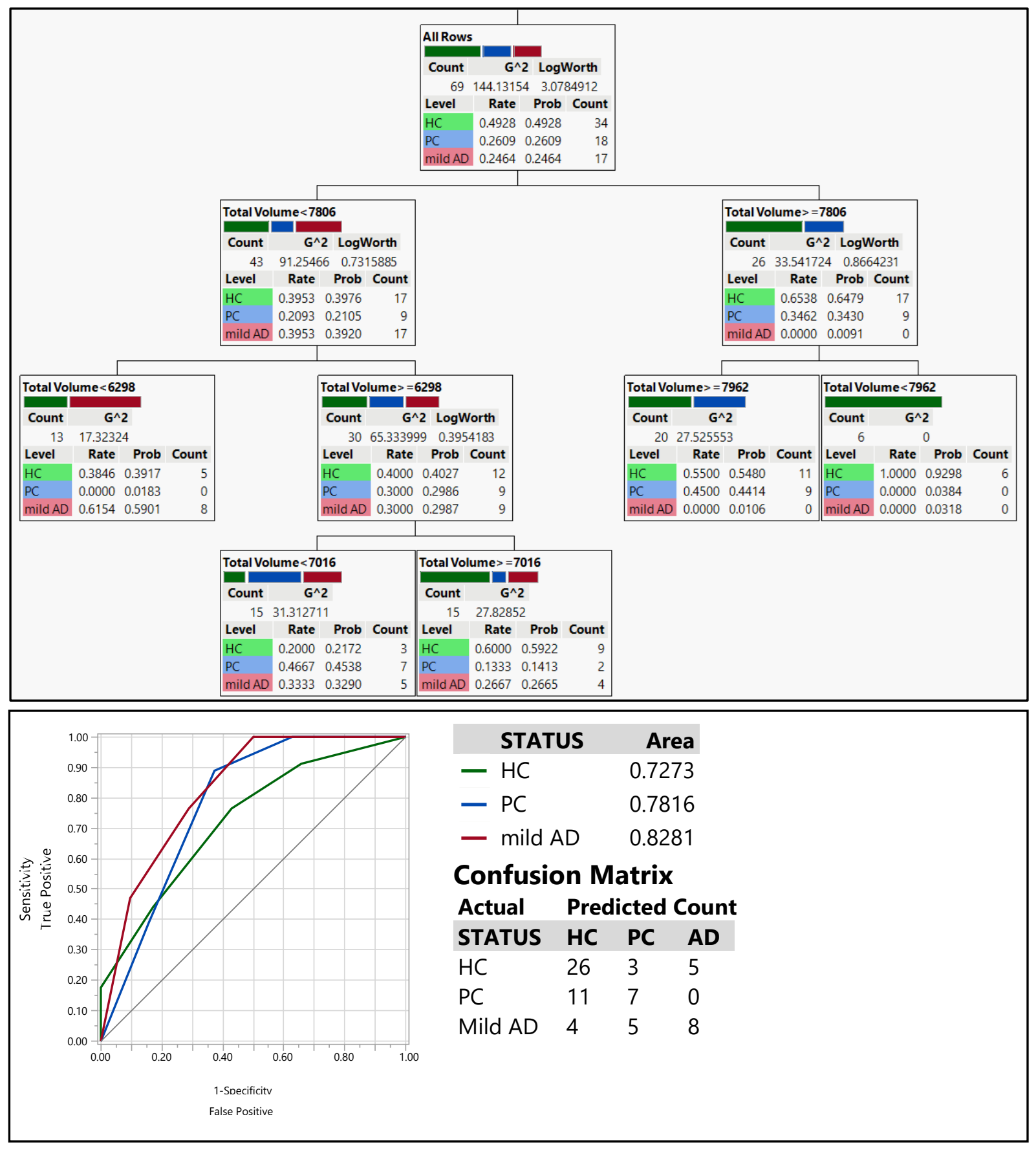

Figure S5. Results of a classification-tree that was produced using hippocampal Total Volume variable as a predictor. The top panel presents the classification tree diagram with threshold's, lower panel presents receiver operating characteristic (ROC) curves, areas under the curves (AUCs), and a confusion matrix. The confusion matrix presents the numbers of correct and incorrect classifications. 
ROC Curves for STATUS $=\mathrm{HC}$

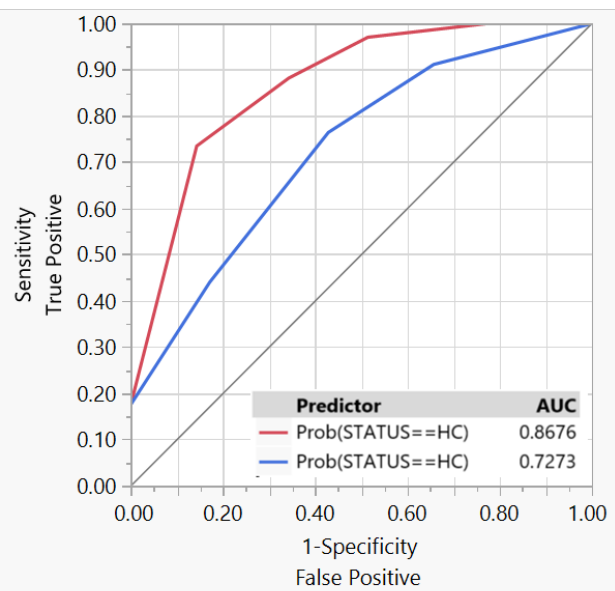

ROC Curves for STATUS $=$ PC

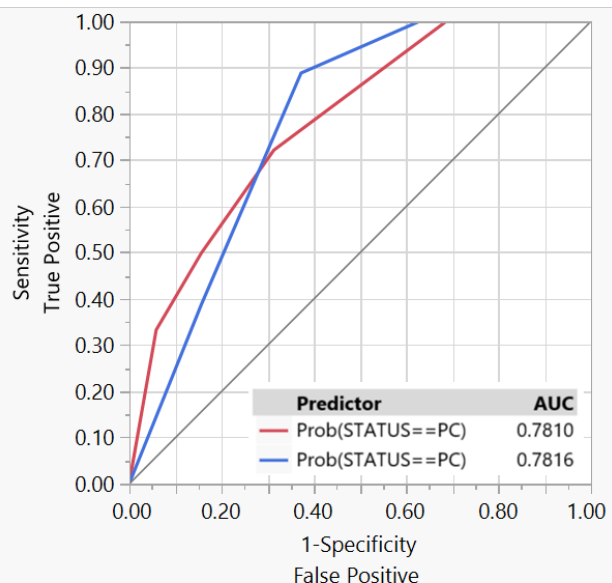

ROC Curves for STATUS=AD

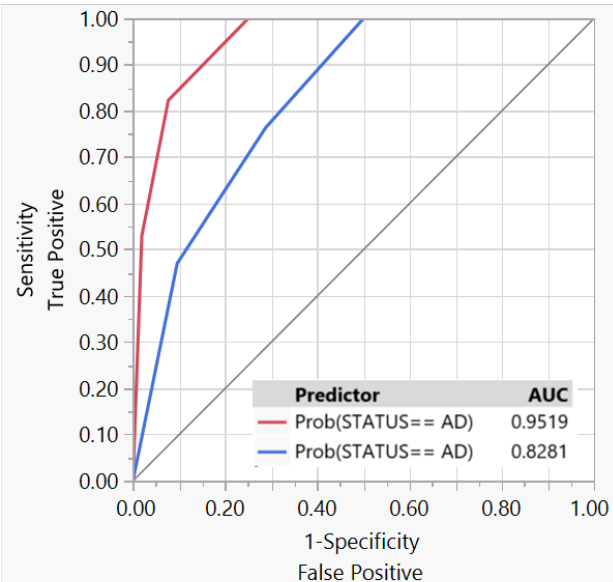

Figure S6. ROC-curve comparisons for classification results based on qGRE metrics versus commonly used tissue atrophy. The comparison of ROC curves created with Dark Matter \& Viable Volume versus Total Volume. The red lines represent Volumes of Dark Matter and Viable Tissue used as predictors, and the blue lines represent Total Volume used as a predictor. Insets show corresponding AUC values.

Significant differences in the AUC values for the ROC curves were found for HC $(p=0.0304)$ and mild AD ( $p=$ 0.0016). For HC Dark Matter and Viable Tissue volumes AUC was 0.8676 (0.7662 - 0.9291, 95\% confidence interval $(\mathrm{CI}))$ and for Total Volume the AUC value was $0.7273(0.5989-0.8265,95 \% \mathrm{CI})$ with $\mathrm{p}=0.0304$. The corresponding results for PC were $0.7810(0.6496-0.8729,95 \% \mathrm{CI})$ and $0.7816(0.6636-0.8665,95 \% \mathrm{CI}), \mathrm{p}=$ 0.9940, and for mild AD, $0.9519(0.8838-0.8910,95 \% \mathrm{CI})$ and $0.8281(0.7129-0.9033,95 \% \mathrm{CI}), \mathrm{p}=0.0016$.
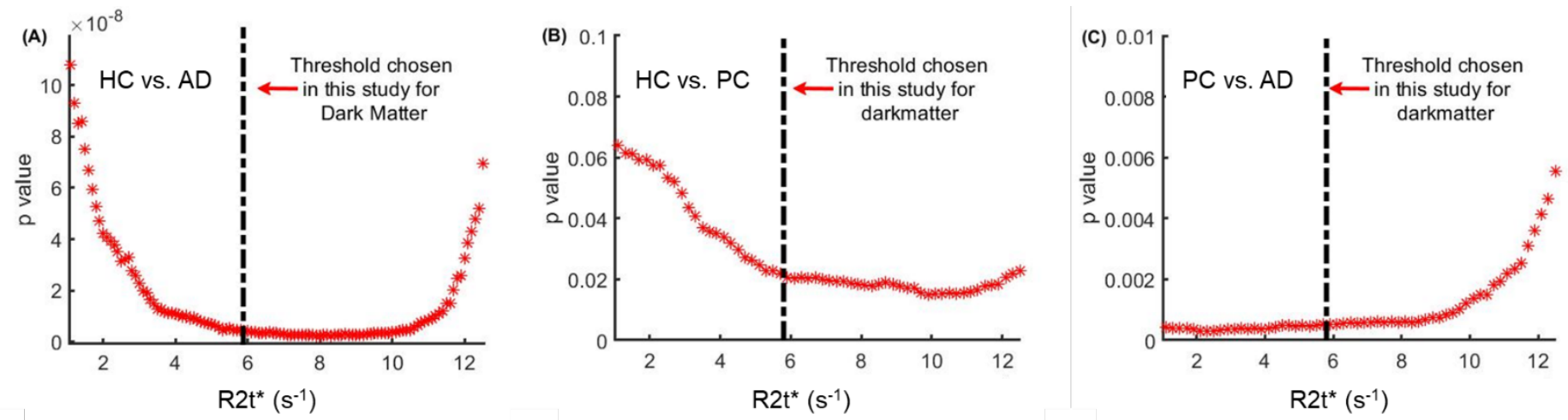

Figure S7. The choice of R2t* threshold for justifying the separation of Dark Matter volume from Viable tissue volume. Plots show dependencies of $p$ value defining significance of group differences between (A) HC and mild AD groups, (B) HC and PC groups, and (C) mild AD and PC groups (using Dark Matter volume as a variable) with varying $\mathrm{R} 2 \mathrm{t}^{*}$ threshold (from $1.1 \mathrm{~s}^{-1}$ to $12.5 \mathrm{~s}^{-1}$ with a step size of $0.1 \mathrm{~s}^{-1}$ ) separating Dark Matter and Viable Tissue. $p$ values obtained from $\mathrm{HC}$ and mild $\mathrm{AD}$ group comparison, were decreasing with increasing R2t* from $1.1 \mathrm{~s}^{-1}$ to $4 \mathrm{~s}^{-1}$, remained relatively stable between $\mathrm{R} 2 \mathrm{t}^{*}$ of $4 \mathrm{~s}^{-1}$ and $10.5 \mathrm{~s}^{-1}$ and then started to increase with increasing $\mathrm{R} 2 \mathrm{t}^{*}$. The $\mathrm{p}$ values between $\mathrm{HC}$ and $\mathrm{PC}$ groups were decreasing with increasing $\mathrm{R} 2 \mathrm{t}^{*}$ threshold and saturated around $6 \mathrm{~s}^{-1}$ till $12.5 \mathrm{~s}^{-1}$ and the $\mathrm{p}$ values between mild $\mathrm{AD}$ and PC groups were small and relatively stable for R2t* values less than $\sim 9 \mathrm{~s}^{-1}$ and then sharply increased above $9 \mathrm{~s}^{-1}$. This result illustrates that the $\mathrm{R} 2 \mathrm{t}^{*}=5.8 \mathrm{~s}^{-1}$ threshold for Dark Matter separation is a reasonable criterion for assessment in AD-related participants. 
Table S1. Summary of mean neuronal count and Dark Matter measurements in five hippocampal subfields. Neuron counts were performed by a highly experienced board-certified neuropathologist, blinded to any neuroimaging data or formal neuropathologic diagnosis at the time of cell counting. Three 40x objective fields (each $0.55 \mathrm{~mm}$ diameter) selected for counting were evenly spaced but otherwise randomly chosen within each area of interest based on boundaries borrowed from FreeSurfer. Neurons were identified by morphology on H\&E stained slides. Plot on the right illustrates an association between actual mean neuronal counts and fractions of Dark Matter in the corresponding regions of hippocampus.

\begin{tabular}{|c|c|c|c|c|}
\hline $\begin{array}{l}\text { Hippocampal } \\
\text { subfields }\end{array}$ & $\begin{array}{l}\text { Neurons per } \\
\text { objective field }\end{array}$ & $\begin{array}{l}\text { Dark Matter } \\
\text { fraction }\end{array}$ & \multirow{6}{*}{ 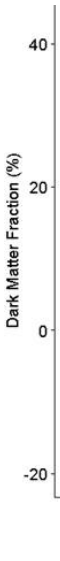 } & \multirow{5}{*}{$R=-0.88, p=0.047$} \\
\hline $\mathrm{CA} 4$ & 21 & $10 \%$ & & \\
\hline $\mathrm{CA} 2 / \mathrm{CA} 3$ & 59 & $3 \%$ & & \\
\hline CA1 & 3 & $23 \%$ & & \\
\hline Subiculum & 1 & $18 \%$ & & \\
\hline Parasubiculum & 8 & $25 \%$ & & ${ }^{20}$ Mean Neuron Cell Countsample 40 \\
\hline
\end{tabular}

Table S2. Statistical analysis of the potential influences of MRI scanners on the data obtained in this study. In this study, the data acquired on four different Siemens 3T MRI scanners (PET-MR, Prisma, Trio, and VIDA). The Fisher-Freeman-Hatton test is an extension of the Fisher's exact test to an unordered $\mathrm{r} x \mathrm{c}$ table for the three groups of participants (HC, PC, and mild AD) and four different MRI scanners were used (PET-MR, Prisma, Trio, and VIDA). The Count, Total $\%$, Col\% (column percent), and Row $\%$ correspond to the data within each cell that has row and column headings (such as the cell under PET-MR and HC). The Fisher-Freeman-Hatton test demonstrated that the three groups of participants (HC, PC, and mild AD) were independent $(P=0.2096)$ of the four different MRI scanners (PET-MR, Prisma, Trio, and VIDA).

\begin{tabular}{|c|c|c|c|c|c|}
\hline $\begin{array}{c}\text { Count } \\
\text { Total \% } \\
\text { Col \% }\end{array}$ & PET-MR & Prisma & Trio & VIDA & Total \\
Row \% & & & & & \\
\hline HC & 5 & 16 & 4 & & \\
& 7.14 & 22.86 & 5.71 & 12.86 & 48.57 \\
& 31.25 & 64.00 & 40.00 & 47.37 & \\
\hline mild AD & 14.71 & 47.06 & 11.76 & 26.47 & 17 \\
& 7 & 5 & 1 & 4 & 24.29 \\
& 10.00 & 7.14 & 1.43 & 5.71 & \\
\hline PC & 43.75 & 20.00 & 10.00 & 21.05 & 27.14 \\
& 41.18 & 29.41 & 5.88 & 23.53 & 6 \\
& 4 & 4 & 5 & 8.57 & \\
\hline Total & 5.71 & 5.71 & 7.14 & 31.58 & \\
& 25.00 & 16.00 & 50.00 & 31.58 & \\
\hline
\end{tabular}


medRxiv preprint doi: https://doi.org/10.1101/2021.04.27.21256098; this version posted April 29, 2021. The copyright holder for this preprint (which was not certified by peer review) is the author/funder, who has granted medRxiv a license to display the preprint in perpetuity.

All rights reserved. No reuse allowed without permission.

Table S3. Mean values and standard deviations (STD) of R2t* distributions for three groups in Dark Matter $\left(\mathrm{R} 2 \mathrm{t}^{*}<5.8 \mathrm{~s}^{-1}\right)$, and Viable Tissue $\left(\mathrm{R} 2 \mathrm{t}^{*}>5.8 \mathrm{~s}^{-1}\right)$.

\begin{tabular}{|r|c|c|c|c|}
\hline \multirow{2}{*}{ Groups } & \multicolumn{2}{|c|}{ Dark Matter R2t* $\left(\mathrm{s}^{-1}\right)$} & \multicolumn{2}{c|}{ Viable tissue $\mathrm{R} 2 \mathrm{t}^{*}\left(\mathrm{~s}^{-1}\right)$} \\
\cline { 2 - 5 } & Mean & STD & Mean & STD \\
\hline AD & 2.2 & 1.6 & 14.3 & 4.8 \\
\hline PC & 2.3 & 1.6 & 14.9 & 4.8 \\
\hline HC & 2.7 & 1.7 & 15.2 & 4.3 \\
\hline
\end{tabular}

